University of Louisville

ThinkIR: The University of Louisville's Institutional Repository

Electronic Theses and Dissertations

1941

\title{
The culture of Louisville as affected by and reflected in motion pictures.
}

Eleanor Blake Carpenter
University of Louisville

Follow this and additional works at: https://ir.library.louisville.edu/etd

Part of the Film and Media Studies Commons, and the United States History Commons

\section{Recommended Citation}

Carpenter, Eleanor Blake, "The culture of Louisville as affected by and reflected in motion pictures." (1941). Electronic Theses and Dissertations. Paper 1696.

https://doi.org/10.18297/etd/1696

This Master's Thesis is brought to you for free and open access by ThinkIR: The University of Louisville's Institutional Repository. It has been accepted for inclusion in Electronic Theses and Dissertations by an authorized administrator of ThinkIR: The University of Louisville's Institutional Repository. This title appears here courtesy of the author, who has retained all other copyrights. For more information, please contact thinkir@louisville.edu. 
UNIVERSITY OF LOUISVIILE

THE CULTURE OF LOUISVILIE

AS AFFECTED BY AND REFLECTED IN

MOTION PICTURES

\author{
A Dissertation \\ Submitted to the Faculty \\ of the Graduate School of the University of Loulsville \\ In Partial Fulfiliment of the \\ Requirements for the Degree \\ of Master of Art.
}

Departmont of History

By

Eleanor Blake Carpenter

Year

1941 
NAME OF STUDENT:

TIME OF THESIS: THE CULTURE OF LOUISVILLE AS AFFECTED BY AND REFLECTED IN MOTION PICTURES

APPROVED BY READING COMMITTEE COMPOSED OF THE FOLLOWING MEMBERS :

NAME OF DIRECTOR:

DATE: Mhareh25,1941 


\section{TABLE OF CONTENTS}

CHAPITR

I

II

III

IV

$\mathbf{V}$
THE DEVELOPMENT AND IMPORTANCE

OF THE MOVING PICTURE . • . . . . 1

LOUISVILIE AT THE MOVIES • - . . 22

MOTION PICTURES AND THE FINE ARTS

IN LOUISVILLE •. • . . . . . . 47

MOTION PICTURES AND EDUCATION

IN LOUISVILLE . . . . . . . . . 69

CONCLUSION . . . . . . . . . 87

BIBLIOGRAPHY . . . . . . . . . . . . . 91 
THE CULTURE OF LOUISVILLE

AS AFFECTED BY AND REFLECTED IN MOTION PICTURES 


\section{CHAPTER I}

THE DEVELOPMENT AND IMPORTANCE OF THE MOVING PICTURE 
CHAPTER I

THE DEVELOPMENT AND IMPORTANCE

OF THE MOVING PICTURE

Motion pictures today are having considerable Influence upon the American people. This condition is true because of the enormous number of people who attend the "movies," bocause of the wide variety of subjects dealt with by the moving pictures, and because (as show by rellablo psychological tests) moving pictures influence the thought and sometimes the bohavior of those who attend thom. On the other hand, the motion picture is definitely moulded by the taste of the public, from which it draws Its sustenance in the form of box-office recelpts. Exam1nation shows that public tasto in moving pictures varies slightly betweon different sections of the country, betwoen cltiog of different sizes, and greatly between rural and urban populations. It is, therefore, the purpose of this thesis to consider what effect motion piotures are having upon the culture of one city-Ioulsville, Kentuoky--and what the attitude of the people of this c1ty reveals in regard to their culture.

Any discussion of motion pictures, to be intelligible, must be preceded by a briof summary of the history of the industry.

The genesis of the moving plcture is found in the 
discovery of how to record motion, made in Rome in 1640 , by Athanasius Kircher. He achleved the effect of moving plctures by painting pictures on glass with revolving disc. ${ }^{1}$ The next forward step was mado oarly in tho ninoteenth century by the Parisian, Peter Roget. 2 After long experiments in opt1cs, he developed the toy zoetrope, in which plctures were alternated with black intervals--as in the moderm motion picture film. But 1t was not until the next step that the present moving picture was mado possible. In 1888 Thomas Edison recorded the first moving photograph. His flrst recordings were made on a cylinder, which, however, he soon discarded in favor of the nerly Invonted Eastman f1lm. ${ }^{3}$ But since the projector ras st111 unknown, Bdison's movio was a peep-show. Some of the typical subjocts wore Sandow the Strong Man, Buffalo Bill, prizo fights and dancers. The peop-show mot with immodiate popularity, but had ilttle room for development, because it could be seen by only one person at a time. Moanwhile, numerous inventors were quietly working on projector. Their labors finaliy rosultod in the Amat Vitascope, which was immediatelJ bought by Edison. And so the moving pleture was born. The Edison camera, Eastman film and Armat Vitascope combined to

1. Ramsaye, Terry, A IIIIIon and One N1ghts - A H1stor of the Moving P1ctures, Now York, SImon and Schuster, 1926, $\mathrm{pp} \cdot 6-7$.

2. Ib1d., pp. 9-10.

3. Ibla., pp. 50-58. 
produce the first true movio. The amazing spectacle appeared Apr11 23, 1896, as the last act at Koster and Beal's Kuslc Hall in New York. The subjocts were Annabelle Moore, a dancer, part of a prize fight and waves on a beach. The audience was wild with onthusiasm. Quickly the new invention swept the country. 1 Movios wore soon shown on all vaudeville clrcuits. Their popularity continued to inoroase, with the result that, on April 2, 1802, the first motion picture theater was opened at 262 Main Streot, Los Ange108.2

Naturaliy the popularity of the new invention gave rise to producing companies. The original company-Edison's--was interested more in mechanisms and patents than in the production of photoplays, so it was nover very important as a producer. Another very early company wag the Lambdo Company, organized by Colonel Latham. It, however, had 1 ts hey-day in tho poop-show era and had begun to decline before the movies wore firmly ostablishod. It sold its rights and patents to Blograph, the company which did most toward the development of moving pictures. From crude beginnings, Blograph progressed rapidly under the guldance of 1 ts $\nabla 1 c e-p r e s i d e n t$ and real manager, Barry Marvin, and its talented young director, David Wark Griffith.

1. Hays, Will, Soe and Hoar, A Brief Higtory of the Moving Plcture and the Development of Sound, November, 1929, pp. 11-12.

2. Ib1d., p. 16 . 
Blograph, in its oarly days, devoloped sconarlo writing and Indoor photography. It placod 1ts main omphasis on directing and was the roal ploneer of story pletures. Anothor early company was Vitagraph, which worked along the same lines as Blograph. St1ll another was Kalom, known chiefly as the ploneer producers of comedy. Because all wore experimenting, ${ }^{1}$ they were friendly, in spite of the fact that they were competitors.

Thus, through the early years of the twentioth century, the new Industry was progressing sat1sfactorily. But all was not as poaceful as it seomed. There was an increasing number of sults over patents, which were serlously hampering progres8. In 1907 it was agreed that all plcture makers could be licensed under the Edison patents in consideration of royalty payments. Immodiately thereafter, the Edison Licensees Group was formed. It Included Kalem, V1tagraph, Lubin, Sel1g, Essanay, Melles and Patho. But Blograph would not jield. It claimed that it had patents as nocessary to the industry as the Edison patents, which it had bought from Colonel Latham. For over a year B10graph and the Edison Licensees Group waged a Vigorous war. Finally, on December 18, 1908, they made peace. Blograph and the Edison LIcensers pooled their patents and formed

1. Griffith, Mrs. D. W., When Movles Were Young, New York, Dutton and Company, 1925.

2. Ramsaye, Terry, op. cit., p. 466. 
the Motion Plctures Patents Company. 1

The new company proposed to license exchanges to doal in the fllms to be made by the Ilcensed studios, which f1lms were to be rented only to theaters using 11 censed projectors. Thero was a charge of two dollars a woek for every 11censed projector. No liconsed theater could handle unllcensed films and no licensed film could be distributed to any unlicensed theater. Most of the industry--producers, distributors and exhibitors--had to submit. ${ }^{2}$ The trust was about to gain a stranglo-bold on the infant industry.

But two mon fought back, Swanson in the distributing ond, and Carl Laemmle in the producing 1ine. Both "wont independent." Laemmle organized the Independent Moving Plctures Company of America, better known as Imp. In spite of numerous suits by the trust, he produced and distributed many good pictures. On May 27, 1910, the world learned that the General Films Company had been organized. Backed and really controlled by the Motion Pictures Patents Company, it had as its object the purchase of all distributing companies. Becauge 1ts competitors could get very little film, they were forced to sell out to the new company. The result was that betweon Apr11, 1910, and January, 1912, the General F11m Company bought the fifty-seven principal exchanges of

1. Ib1d., p. 472.

2. IbId., p. 487 . 
America. I St1ll Laemmle fought on. Backed by Theodore Roosevelt, he fought the trusts through court after court, until on October 15, 1915, the United States government ordered the trusts to discontinue all unlawful practices-which meant their imodiate dissolution. 2

In 1912 Imp was reorganized as Universal, with Carl Laemine as president. 3 In 1913 he announced the adoption of a now policy, "quality rather than quantity"-the policy which Universal has followed ever since. 4

Gradually, through steps which if rolated in detall would f1ll volumes, the aforementioned companies evolved into total of 103 producing companies in the United States. In 1922, Will Hays organized the Motion Plcture Producers and Distributors of Amorica, which states that Its object ig "to foster the common interests of those engaged in the motion picture industry by ostablishing and maintaining the highest possible moral and artistic standards of motion plcture production, by developing the educational as well as the entertainment value and the general usefulness of the motion plcture, and by reforming abuses relative to the industry." The Hays' offlce further states that 1t operates on the principle that every plcture which

1. IbId., p. 528.

2. Drinkwater, John, Life and Adventures of Carl Laemmle, Now York, G. P. Putnam's Sons, 1931, pp. 83-130.

3. Ib1d., p. 168 .

4. IbId., p. 226. 
reaches new high of intellectual or artistic achievement brings a new audience to the movies.

An interesting phase of the history of moving pictures is the rise of the star system. Originalig the producers, with the one exception of Carl Laemmle, were derinitely opposed to stardom. Except in Imp, not oven the names of the players wore known to the public until 1912. In the beginning, this lack of publiclty was wholly agreeable to the actors, most of whom were rather ashamed to be connected with the mories, as such association usually stamped thom as stage fallures. Salaries were low, from twenty to forty dollars a wook for the best actors, and the work was hard. But the players wero sustained by foeling of ploneering and a belief in the future of the motion picture. I In 1910 Carl Laemmle began the star system with a publicity stunt for Florence Lawrence and King Baggot. 2 From that time on, he gave a great deal of publicity to h1s players, who soon found it pleasant to be publiosidols In any capacity. He also offered his actors higher salaries than the other producers. Consequently, he not only got all the best actors but he also pleased the public. The result was that the other producer had to give in and the star system was soon firmly established. Some of the early popular stars were: Florence Lawrence, Blograph--then Imp;

1. Griffith, Mrs, D. W., op. c1t, pp. 140-142.

2. Ramsaye, Terry, op. c1t., pp. 523-524. 
King Baggot, Imp: Henry Walthall, Blograph; Mary P1ckford, Blograph; Mabol Norman, V1tagraph; John Bunny and Flora Flnch, Blograph; Tom M1x, many companies; Norma, Constance and Natalie Talmadgo, Vitagraph; Allco Joyco, Kalom;

Florence La Badie, Kalem; LIllan and Dorothy G18h, Blograph; Mao Marsh, Blograph; Mack Sennott, Biograph.

Undoubtedly one of the most important phases of the history of moving pictures is the evolution and development of the foature film. Compared with today's productions, the early flims were rudimentery. They were short and usually pointloss. The malnsteps in the dovelopment of the feature film can be seen from the following pictures:

1. The Great Train Robbery, 1903, notable because it was the first 111m with a roal story; it was olght hundred foet long and was the first film made on location.

2. The Violin Maker of Cremona, 1909, Introducing Mary P1ckford.

3. For Love of Gold, 1909, in which a close-up was used for the first time.

4. Captain Barnacle, 1910, Introducing John Bunny and a new type of comedy.

5. Queon El1zabeth, 1911 (Fronch), gave American producers some 1dea of the costume play. 6. The M1lilon Dollar Mystery, 1912, popularizing the

7. Enoch Arden, 1912, two thousand foet long. At First It was shown in two instaliments, but was soon shown as one picture. Its popularity proved that audiences liked longor films, and thereby made possible great advance. It also used cut-backs for the first time. 
8. T11110'g Punctured Romance, 1914, Introducing Charilo Cheplin and foaturing Mario Dressier.

9. The B1rth of a Nation, 1915, directed by David Griffith. He took six months to make the picture. There were six wooks of rehearsals before a single shot was made. Ita plot, spectaclo, settings, acting and directing were superb. It advanced the moving picture to the point whero it was a serlous rival of the stage.

10. Intolerance, 1915, the greatest of the Griffith spectacles. It took a year and a half to make and cost two million dollars. But it was too abstract to please the masses.

11. Broken Blossoms, 1919, showing that a simplo, human story has great appoal.

12. Orphans of the Storm, 1922, excellent costuming and tochnique.

13. The Covered Wagon, 1923, began the rogue for op1cs.

14. The Ten Commandments, 1924, combination of the spectaclo and the so-called classical style. It made great progress in the process and use of trick photography.

15. What Price Glory, 1926, showing the possiblities of movies as peace propaganda.

16. The B1g Parade, 1926, also peace propaganda.

17. Ben Hur, 1926, noted for costumes, thr111s, good spoctacio and good acting. It aroused interest partiy by means of sound effects which were produced by an orchestra traveling with the picture. It was first presented as a road-show.

18. The Jazz Singer, 1927, proved that sound was practicable.

Obviously, the subjocts and settings of the feature film offer infinite scope for varlety. It may portray any part of the globe, any era, anj strata of socloty. It can also prosent a vast number of 1deas and skills. Immediately upon the development of the feature 
picture, movements were begun to reform the movies. on Christmas ove, 1904, Mayor Mcclellan of New York closed overy nickelodeon in the c1ty. The result was the formation of the Peoplo's Institute, a voluntary organization, wh1ch, In 1909, established the unpald National Board of Censorship. The producers agreed to make anj changes which the board wanted in their pictures. The board was finaneed by charging the producers three dollars and a half for every thousand feot of film reviewed. (The cost to producers is now six dollars and a half for every thousand feot.) The board never liked its name, as it was really more interested in educating the public to approciate good pictures than in consorship. Therofore, in 1916, it changed its name to the National Board of Review of Motion P1cturos. It both consors pictures and classifles them as "mature,". "family," or "fuvenfle." In 1911 a number of official local censorship boards were sot up. They wore, howover, satisfactory to no one, as they varied greatly in what they cut and what they passed. Those in oxistence today are two city boards-Boston and Chlcago, and seven state boards--Florida, Kansas, Maryland, Now York, Ohlo, Ponnsylvania and V1rginia.2

The Catholic Church has taken a loading part in movements for reforming moving pictures. In 1932, the Intornational Federation of Catholic Alumna began reviowing

1. To1d., PP. 473-485.

2. Mimeographed material and correspondence with the Will Hays Office, 1937-1940. 
films. The church was so ploased with 1ts work that the bishops requested the foderation to continue its reviews-with classifications. These classifications are: A f1lmsfully approved; B films-partly objectionable to some phase of church doctrine (as sulcide beling made honorable in Coiling zero. The roviow oxplains just why the picture 1s considered questlonable, then leaves attendance up to the Individual conscionce.) C fllms- Platly condemned. (These are very fer.) That these classifications influence the movie attendance of Catholics--and there are twenty million of them in the United States--1s soen by the fact that whonover a New York theater shows a film before its classification has been made public, the theater is besleged with tolephone calls inquiring whothor it is $A, B$, or C.

The best known movio reform work of the Catholic Church was 1ts "clean-up campalgn" started in 1934. In the years immodiately prior to that date, vulgarity had undoubtedly infectod many films. Nor can we justiy condemn the producers. The public attended the vulgar type of pioturo, so naturally the producers gave the public what it seemed to want. Then the Cathollc Church formed the Legenl of Docency, organized many local Better Films Councils, and began an active campaign for better pictures. The producers rosponded Immediately with such foatures as The Life of Pastour and Zola. Honestly expocting those films to play to ompty houses, the producers wero surprised to find that they 
drew falrly good audiences.

This improved standard of purity has boon maintainod. Moreover, the producers have tried to ralse the public taste in films, artistically as woll as morally. As Will Hays says in his 1939 roport as president of the Motion P1cture Producers and Distributors of America:

The increasing number of plctures whlch treat honestly and dramatically many current themes proves there is nothing incompatible botween the best interests of the box-office and the kind of entertainment that raises the lovel of audience appreciation whatover the subject treated. . . An ontertainment art for millions has risen to ouch high estate that the best which the living theatro can create is now demanded from the films. It is not so long ago that thriling action for its own sake was considered a satiafying movie; that the custard pio was the symbol of hilarity and amusement from the scroon; that the chase was sure-fire entertainment technique; that boymeots-girl supplied all the drama that a motion picture audience apparently demanded.

While the feature pleture was developing, so also were numerous types of shorts. Travel plctures were very popular in the early days of moving plctures, but lost much of their popularity as other types of pictures developed. Among the most popular kinds of shorts todey are nows reels. They began by explorers and adventurers taking their own p1ctures, which wore retouched by the studios. The f1rst motion picture of current events was of McKinley's inauguration in 1897. Scenes of the Spanigh-American War were made and exhlbitod by Edison. Nows reols gradually increased in scope and popularity, but it was not unt1l the inauguration of Woodrow wilson in 1913 that they became a regular part of 
movie programs. The earliest news-reel company was Kinegrams. With the advent of sound, news-reels received so great an impetus that now the public demands them. By far the most popular today is the March of Time.

Another type of short is the educational picture. Countless early experiments with it were made, but none wore very successful. In 1922 research work in this field was begun under the auspices of the National Education Association, In the University of Chicago, by Charles H. Judd. Other experiments were made in 1923 by Teachers College and Yalo University. The results were the Yalo Chronicles of America in photoplay. In 1929 was begun the Secrets of Success Series sponsored by the Public Relations conference's Committeo on Social Values in Moving Plotures. The subjects of these pictures are scenes from feature flims in one reel, illuatrating life situations. Their object is to teach right conduct. Todey they are used in one hundred and forty-nine schools, where the teachers generally agreo that they actually chango conduct. 1

The lastmborn child of the moving pleture industry-the cartoon--1a the most beloved by the American public. Cartoon pictures first beoame popular during the World War. The earliegt popular series was "Out of the Ink-well." The plctures were very short. Both sound and color were required to increase either the length or popularity of I. IbId. 
cartoon pictures. But today, the Walt Disney productione load all other pictures in popularity.

Sound and color have also given rise to numerous other shorts, most of which are semi-educational, such as Popular Solence and Unusual Occupations.

At this point it is well to consider the development of color and sound in motion plctures. Experiments were made along both lines from the peep-show days. Color achioved tolerable success long before sound, with the productiong of the Kinemacolor Company in 1912. Unfortunately, however, the company camo to an abrupt ond within a joar, owing to the death of 1 ts president, Mr. Brock. However, others continued to work w1th color. In 1929 the two-color technicolor process produced a film, On with the Show. In 1932 Walt Disney began to uso his throe-color process. The first reature longth picture photographed by the now process was Becky Sharp, producod by Rouben Momoulin, with Robert E. Jones supervising the color. Since then there heve beon many exquisite color films such as the Garden of Allah and Robln Hood. But tho color process st1ll has much to accomplish. It is unreliable, some colors registering better then others, and it is expensive.

The development of sound pictures was slower than color in the early stages, but once made practical at all, 1t developed far more rapidly. The earliest sound device was Bdison's Kinotoscope of 1894, a peep-show with a 
phonograph and oar-tubes. In 1908 Carl Laemme showed his Synchroscope in Indianapol1s. It was at f1rgt succossful, but died young because it could hold material for only two reels. In 1913 Edison oxhiblted his cameraphone, which falled because of poor synchronlzation. About 1921 varlous American ongineers began oxperimenting with the main problems of sound pictures--namely, to produco satisfactory qualities of sound in adequate rolume. As so often happens with invontions, several groups of scientists working independently obtained satisfactory results at approximately the same time, in 1926. Most notable was the work done by the Bell Laboratories. The now invention was called the vitaphone. At rirst no producer could be induced to take it serlously, with one exception, Sam Warner. He Immediately saw Its possibilities and persuaded his three brothers to equip the Warner stud1o for sound.

The first sound pictures were presented to the public on the sixth of August, 1926, in the only theater then equipped for sound, the Warner's own theater at Broadway and Fifty-Second Street, Now York. They consisted of an introductory speech by 111 Hays, songs by Martinell1, Marion Talley, Anne Case and the Metropolitan Opera Company's chorus, and violin selections by Zimbalist and Elman. There was also an orchestra synchronization for the feature pleture, Don Juan. Criticisms were favorable, the audience was greatly interested, but st1ll the producers did not take sound 
serlously, because they did not bellove that it could be used successfully for dramatic speech. Only the Warner brothers persisted. Finaliy, on the sixth of 0ctober, 1927, they presented Al Jolson in the Jazz Singer, in whlch not only mus1c but also speech was used successfully. The motion picture industry was immodiately rovolutionized. ${ }^{1}$

The development and growth of the industry have been continuous. The money invested in the moving picture theaterg of the United States today is approximately two b1llion dollars. The average price of admigsion is twentyfive cents, and the annual total of pald admissions is a 11ttle over one billion dollars. Here is how every dollar recelved at the box-office is spent:

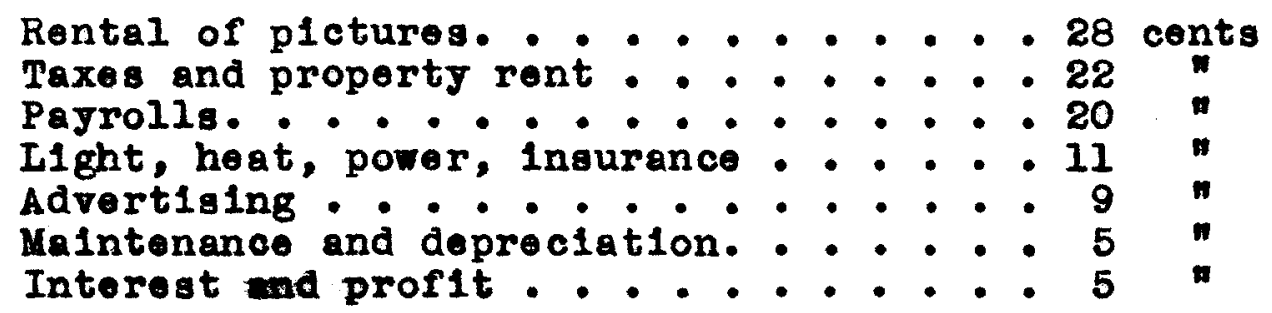

The Hollgwood studios spend annually about one hundred million dollars in producing betweon five and six hundred feature-length pletures. They produce more than twice this many shorts. This is eighty per cent of the motion pictures of the world. In Amerlca, nearly half a million miles of film is used annually. A large studio consumes in one year enough electric current to supply

1. Hays, W11, op. C1t., pp. 38-51. 
thirty-three thousand homes for the same perlod. The industry omploys some two hundred and seventy thousand poople. The cost of a feature picture varies from fifty thougand to several million dollars. Two hundred and sevonty-six different industr1es, crefts and arts are involved in the making of a plcture. Ususily two hundred and fifty prints are made from each original film. The mater negative is carefulig pregerved at the studio. The prints are distributed to the theaters through film exchanges located in thirty-two citios in the United States. I Elghty-five million Americans attend the movios overy wook. Of course some of these are "repeaters." The producers, through an experimental poll in 1937, estimated that there were about twenty-g1x million Americans over twelve years of age who attend the movies rarely or not at al1. In the United States there are seventeon thousand motion pleture theaters, providing one seat for every fifteon Amoricans. These theaters are located in nine thousand towns. There are one hundred and seventy-five theaters in oighty-five communitios which show forelgn f1lms, but only about half of these show forelgn pictures exclusively. In the United States, only the nogroes are under-gerved by the movies. Approximately only one seat

1. Mimoographed material and correspondonce 1th the W11l Hays Office, 1937-1940. 
is avallable for every twenty-one thousand negroes. ${ }^{1}$ The producers desire most to please people with incomes of upwards of fiftoen hundred dollars yoar, living in clties of upwards of fifty thousand inhabitants. In the betterclass houses it is the adult female who predominates heavily. "She wants opportunity to escape by reverie from an existence which she finds insufficiently interesting." 2

We have seon that a largo number of Americans attend motion pictures and that these pictures deal with a great variety of subjects. The vital question is, therefore, to what oxtent are the audiences influenced by what the soo? The most nearly adequate answer to this question is found in the research work which is sponsored by the Payne Fund and done by competent peychologists. The object of th1s research was to ascertain "what is the amount of knowledge gained and retained from motion pictures by children of various ages, and the types of the knowledge most 11keiy to be retained, ${ }^{3}$ and also to ascertain the effects of motion plctures upon childrens' emotions, 1deas and behavior. For the sake of comparison, many of these tests were given to aults as well as to children. They were made by such men as W. W. Charters, Director, Bureau of Educational Research, Oh1o State University; Wendell

1. Will Hays Roport, March 27, 1939.

2. Thorp, Margaret Farand, America at the Mov1eg, New Haven, Yalo Unlversity Press, 1939.

3. Charters, W. W., Director, Bureau of Educational Research, Oh10 Stato Univeraity, Motion Plctures and Youth, New York, Macmillan, 1833, p. 2 . 
Dysinger, Department of Psychology, State University of Iowa, and others of like calibre. The results of the tests are tabulated in twelve monograms published by Macmillan. They show some interesting findings in regard to the emotional responses, perception and retention of Idoas and incident, and effects of motion pictures on attltudes and behavior of children who attend them.

In the emotional realm, it was seen that the curve of response to scenes of danger, conflict and tragedy reaches 1 ts poak with childron of nine years of age, begins to decline rapidly at sixteon, and is woak in adults. On the other hand, response to love scenes is totally absent at nine, is very weak up to fourteen, reaches its poak at sixteon, and is woak in adults. ${ }^{1}$ At all ages "Emotional responses are to specific incident. Subjects are largely interested in and moved by the scene of conflict or of danger or of love rather than by the pleture as a whole. In many films there was little or no appreciation of the final outcome. $n^{2}$

In regard to understanding and retention of plot, Ideas and incident, it was found that a high standard was attalned by all age groups. This is probably due to the

1. Ib1a., p. 27.

2. DygInger, Wendell S., Department of Psychology, State University of Iowa, and Ruckmick, Christian, Professor of Psychology, State Un1versity of Iowa, The Emotional Responses of Children to the Motion Picture Situation, A Payno Fund Study, Now York, Macmll1an, 1933, p. 116. 
fact that movies are impressive because they provide Imagery (both visible and audible), have dramatic form, and are usually attractive. In tests for perception of plot, 1deas, and incident, it was shown that adults get 87.8\% of the items on which they were tested; children in grades nine and ten get $80.9 \%$; grades five and $s 1 x$ got 65.9\%; and grades two and three get 52.5\%. Retention is remarkably high. After three months second and third grade children romember ninety per cent of what they got from the picture in the first place. Children of all ages accept what they seo in tho movios as absolute fact. Adults accopt most of what they 800.1

The tests also indicate that the attitudes and behavior of children 18 Influenced by what they seo at the movies. A number of children were shown sons of Gods, The B1rth of a Nation and All's Quiet on the Western Front. The curve of the subjects' attitudes toward Chineso, negroes and war shifted greatly as a result of these pictures. It shifted still more (In the same direction) with some of the children who were show other plctures dealing with the same subjects. At the ond of elghteen months the effects had not worn off. ${ }^{2}$

In regard to behavior, the reports imply that delinquent children are more affected then others. The

1. Charters, W. W., op. c1t., pp. 8-10.

2. Ibid., pp. 20-23. 
21

roport states, "Crime plctures have a pronounced offect upon delinquents." The children copy cues and techniques of minor crimes. The report also states that sex plctures have an extremely powerful offect upon many delinquents, and that for all chlldren "movios constitute patterns of conduct in day-dreaming, phantasy and action."l

Moving pletures are today a feature of American I1fe which we cannot afford to ignore. The factors which make them important throughout the United States, are present in Louisville. This thesis will proceed to examine one important phase of motion pictures in Loulsv1110, namoly, the culture of Loulsvilio as affected by, and reflected in, moring pictures.

I. IDId., p. 16. 
CHAPTER II

LOUISVILLE AT THE MOVIES 
CHAPTER II

LOUISVILLE AT THE MOVIES

Loulsville is in many respects a representativo American city. It is neither northern nor southern, eastern nor western. It is nelther very large nor very small. It is not extremely wealthy nor extremely poor. It has a relatively small forelgn population. Therefore in studying the motion picture situation in Loulsville wo are to some oxtent studying it in America. Louisville has been a good "movie" town almost from the beginning of the industry. The general trond of the history of motion pictures in Loulsvilie reflects that of the country at large.

The first moving picture play in Louisville, Miss Jorry, was seon on Fobruary 18, 1898, at Library Hall. It was roceived with great enthusiasm, more of course, as a wonder and novelty than as dramatic art. Throughout the early nineteen hundreds moving plctures were shown as last acts in the local varlety theaters, as was happening throughout the United States. On Apr11 6, 1904, the f1rst regular motion picture theater in Loulsville was opened. It was the third moving plcture to be opened in the United States, the first boing in Los Angeles, and the second in New York. The Loulsville theater, called Dreamland, was located on Market Streot near Fifth. The new enterprise 
proved so successful that soon its owner, Mr. Irvin Simon, with Judge Alion KInney, formed the Princess Amusement Company wich opened three more moving picture theaters-the Columbia, tho Casino and tho Orphoum. ${ }^{1}$

The first motion picture theater of any size in Louisville was the Majestic at 544 Fourth Stroet. Built by group of Louisville business men headed by Mr. Louls J. Dittmar, it oponed on Christmas day, 1808. Its orlginal seating capacity was six hundred and fifty, but it attracted such large audiences that in 1912 it was rebuilt to accomodate one thousand patrons. It was in this theater that Loulsville roally learned to love movies through the work of such players as John Bunny and Flora Finch, Mary Plckford and Marguerite Clark. During this period, the Majestic had music typical of the motion picture theaters of the country. It had a good orchestra and two foature singers, Amanda Gray and Joe Ramser, who regaled the audience with 1llustrated songs. In 1924 the Majest1c was bought by the KeIth interests. Its audiences began to diminish shortiy afterwards, as was happening all over the country. On January 1, 1929, the property on which the theater was bullt passed to now owners and the Majestic ceased to oxist. ${ }^{2}$

The next theater in Loulgville to show motion

1. De1tz, Martha, "Bringlng the History of the Theater Up to Date, Loulsville Courier-Journal, July 2, 1922.

2. Loulovilie Eerald-Post, September 21, 1928. 
pictures exclusively was the Mary Anderson at 612 Fourth Streot. From 1907 it had beon mun as a vaudeville house. In 1910 1t was bought by the Kelth circult. Then, when in 1913 Kelth's acquired the National Theater, they operated the Natlonal for vaudeville and the Mary Anderson for movies. Soon, however, the Mary Anderson returned to vaudeville and had a chockered career unt1l 1933 when 1t again became motion picture theater and has remained so ever since. 1

Another early motion picture theater of importance in Louigville was the Alamo, on the wost side of Fourth Streot between Walnut and Liberty. It was the inspiration of "M1ke" Sw1to and Dennis Long, who about the same time organized the Fourth Avenue Amusement Companj, with Mr. Dolle as president. The Alamo openod on Thanksgiving Day, November 26, 1914, with Dough and Dynamite, featuring Charlie Chaplin. Shortly afterwards, it introduced a very successful musical novelty. On each side of the screen thero was a box containing an orchostra. One was a jazz band, the other a Hungarian orchestra, which presented "classical" music. The two orchostras plajed alternately and recelved falrly oqual applause. The Alamo's early years were successful, but in 1925 it felt the general movio slump. In 1928 it was wired for sound and was rom opened on the day of the opening of Loew's new theater. 1933. 
But with the opening of the newer theaters nearer Broadway, the Alamo's clientelo changed rapidly. In May, 1937, the Fourth Avenue Amusement Company gave 1t up, and it became the ohio, which has since been torn down.1

During the decade of 1910-1920 nelghborhood houses were coming into existence. Two of the earliest were the Cherokee at Bardstown Road and Bonnycastle, and the Crown on Seventh Street noar 0ak. No1thor is in oxistence today. But the nelghborhood houses continued to increase in number and to improve in quality. The process is still going on. On Fobruary 10, 1916, Lou1sv1llo's f1rgt really good negro movie theater opened. It was the Palace, one of the earliest up-to-date negro movie theaters in the country. 2

On May 11, 1921, Louisvillo's movie lovers were elated over the opening of the Rialto, 616 Fourth Street, then acclaimed the finest moving plcture theater south of Chicago. It was built by the Majostic Amusoment Company at a cost of one million dollars. With a seating capacity of thirty-one hundred, 3 the Rialto is st1ll the largest moving picture theater in the city. Its early programs, characteristic of the grandiose 1deas of moving pictures of the time, consigted of an overture by the Rialto symphony Orchestra, a scenlc plcture with orchestra accompaniment,

1. Courler-Journal, March 16, 1933.

2. Ibld., Fobruary $10,1916$.

3. Ib1d., MaJ 11, 1921 . 
a song specialty, a nows-reel, an organ concerto, Novelty Film Flashes, a prologue by the Rialto operatic quartette, the feature picture and comedy finalo. The program was changed twice a woek. In Fobruary, 1931, the Rialto was bought by the Fourth Avenue Amusement Company, when Mr. Johnson Musselman was made manager. ${ }^{1}$ For a brief time it tried vaudevilie programs, but soon adopted 1ts present polley of movies only.

On October 6, 1921, Loulsvilie's f1rst down-town second-run house was opened at 651 Fourth Street. It was the Kentucky, the first theater in the state of that name. It was, and 1s, manegod by Mr. Simon Swito. ${ }^{2}$ It was oxtensively remodeled in 1940 .

In 1923, the Strand, $326 \mathrm{~W}$. Chestnut, formerly the Schubert Theater, was acquired by the Fourth Avenue Amusemont Company. Two years before that time it had shown movies for a short time, but nover regularls. In 1923 it became moving pleture houge and has remalned so ever since. 3 To the Strand belongs the distinction of boing the flrst theater in Loulsville and the second in the ontire world to have permanent wiring for sound, the first being the Warner theater in New York. In August, 1926, the Strand showed the first sound pictures ever made--the shorts described in Chapter One. 4

1. Horald-Poat, Fobruary 15, 1931.

2. Cour1er-Journal, October 6, 1921 .

3. Ib1d., Fobruary 9, 1923.

4. Himeographed material from the Will Hays office. 
September 1, 1928, saw the opening of Loow's United Artists State Theater, $625 \mathrm{~s}$. Fourth. The bullding was, and 19, the "last word" in moving pleture theater architecture. Its cost was about two million dollars, and its seating capacity is three thousand and fifty. It was the first theater in Louisvilio to have "rofrigeration," as the press of that time called 1t. Its chief architectural distinction is 1 ts open sky effect. The local press, at the time of 1ta opening, made the following comment on Its program policy: "Many this past wook expressed surpriso over the character of the entertainment. It was expected that rauderille would be offored together with plotures, but instead, the management announced, for a flrst bill at loast, a synchronized programme which, of course, is now no novelty for Louisville, as the Strand's bills have beon, In many instances, entirely synchronized. Loew's w111, however, atart the innovation of a sound comlc, Metro's 'The Old Gray Mare,' said to be novel film of its kind." 1

In 1930, the Brown Theater, which had been showing road shows and stock, was wired for sound and became permanently a moving plcture theater. ${ }^{2}$

There have been other down-town theaters in Loulsville which ran moving pictures for brief intervals, but

\footnotetext{
1. Martin, Boyd, articio in Courler-Journal, August 26, 1928.

2. Herald-Post, Fobruary 1, 1930.
} 
none were of importance in the development of motion pictures in the city.

The reception which moving plctures mot with in Loulsville corresponded to thelr reception throughout the country as a wholo. At first they were recelved as an interesting novelty, and were shown mainly as an appanage to vauderille programs. Gradually, however, they completely replaced vaudoville, ospectally after the introduction of sound. We have seen how the Louisville vaudeville theaters one by one changed to motion pictures. Sound also made it possible for motion plctures to compote successfully (IInancially at least) with legitimate stage drama. The only Louisville theater in existence after the invention of movies which never had to succumb to pletures was Macauley's. It was beloved by Lou1sville audiences and provided excellent plays for them from 1875 unt1l 1925. In that year it was torn down for reasons concerning the property on which 1t was located, and was succeoded by tho Brown Theater. Probably, however, even Macauley's would have had diffleulty in competing with moving plctures after sound was established. Movies were taken more seriously hore, as elsewhere, as the feature picture developed, espocially after the B1rth of a Nation in 1915. But by 1920 they seomed to have reached the limit of their development, and in the yoars shortly following there was a nation-wide slump in box-office recolpts. Then came 
sound, which revived and increased interest in moving pictures to such an extent that in 1930 Loulsvilie's only remaining legitimate theater, the Brown, became a motion picture house. There was of course some decrease in boxoffice recelpts during the early years of the depression, but the motion picture industry on the whole suffered 1098 than most businesses. Porhap one reason for their rolative business success was the introduction of double features, which was the 1dea of the producers. Skeptical at first, the exhibitors soon recelved the plan with enthusiasm.

In 1939 motion picture attendance reached its poak.

The managers of the Louigville theaters report that there has been a slight decrease in attendance since the accelerated tempo of the European war, but comedies hold their own and more.

The development of Louisville's taste in moving pictures can best be ascertained by determining wat pictures have been popular here. According to the managers of our local theaters, the following plotures bave had marked popularity in the city:

1903 The Great Train Robbery.

1910 Captain Barnacle, 1th John Bunny.

1912 Enoch Ardon, The Now York Hat, with Mary P1ckford, and the seria1, The Mililon Dollar Mystery.

1918 The B1rth of A Nation.

1914 Till1e's Punctured Romance, with Charlie Chaplin and Mario Dregsior.

1915 Intolorance.

1916 The Imaigrant, Charlio Chaplin.

1918 Dog's Life, Charlio Chaplin.

1919 Broken Blossoms, L11lian G1sh and R1chard Barthe1mess. 
1920 The Three Musketeors, Dougl as Falrbanks.

1922 Grandma's Boy, Harold Lloyd, Orphans of the Storm, With the Gish sisters; and Tess of the Storm Country, with Mary Plckford.

1923 The Covered Wagon.

1924 The Ten Commandments.

1926 The B1g Parade, What Price Glory, Ben Hur.

1927 The Jazz Singer, Al Jolson.

1928 Laurel and Hardy in B1g Business.

1929 Disrael1, Goorge Arliss, Sunny S1de Up.

1930 BIg House, Wallace Beory.

1933 State FaIr, Will Rogers.

1934 The Thin Man, Bengal Lancer, The Herry W1dow, Cetherine the Great, Private Life of Henry VIII.

1935 Mutiny on the Bounty, The Informer, Crusades, The Ghost Goos West.

1936 The Groat Zlogfeld; Moderm Times with Charles ChapiIn.

According to the census of 1940 , the population of Louigville 1s 318,952 . Of this population approximately $47,354^{l}$ are negroes, which leaves a white population of 271,598. The aggregate seating capacity of the moving pleture theaters of the c1ty is 30,784 . The total seating capacity of the theaters for white people is 27,072 , wh1le for negroes it is 3,012. Therefore in Loulsville there is one seat for every 10.36 Inhab1tants--one for overy 10.068 white Inhabltants and one for every 15.72 negro inhabitants. As noted in Chapter One, throughout the United States, there 1s one seat for every fifteon inhabitants and only one for every twenty-one thousand negroes. So we soe that the seating capacity of the Loulsvilie theaters is above the average for the country--especially for negro audiences. The motion picture theaters of Loulsville today are:

1. Negro Year Book, 1930. 


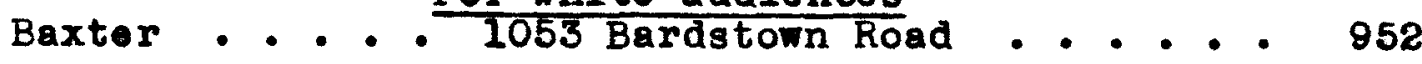
Brown . . . . 315 w. Broadway . . . . . 1491 Cap1tol . . . 2139 S. Preston . . . . 832 Cozy . . . . Third and Central Ave. . . . 350 Crescent H111 . 2862 Frankfort Ave . . . . 514 Downs . . . . 3423 Taylor Boulevard . . . 300 Broadway . . $816 \mathrm{E}$. Broadway . . . . 1338 H1land. . . . 4302 Park Boulevard ..... 275 H1lltop . . . 1757 Frankfort Ave . . . . . 496 Hippodrome. . . Second and Market ....... 400 Ideal . . . . Twonty-Third and Market . . . 1187 *Kentucky .... 651 S. Fourth ........ 796 Loew's United

Artists Stato $625 \mathrm{~S}$. Fourth ...... 3050 Mary Anderson .. $612 \mathrm{~S}$. Fourth ....... 1405 Norman . . . Twonty-First and Portland . . 308 Oak . . . . 1169 D1xio H1ghway . . . . . 750 Orphoum . . . Jefferson near Elghteenth. . 1090 Park . . . . Forty-First and Market . . . 774 Parkland ... 2811 Dumesnil ........ 448 Rex ...... $408 \mathrm{s.} \mathrm{Fourth} \mathrm{........} 700$ Rialto. . . $616 \mathrm{~s}$. Fourth . . . . . 3100 Ritz ..... 1601 S. Second ....... 560 Saroy . . . 211 W. Jefferson ...... 700 Sharnoe ... . 3725 w. Broadway . . . . . 490 


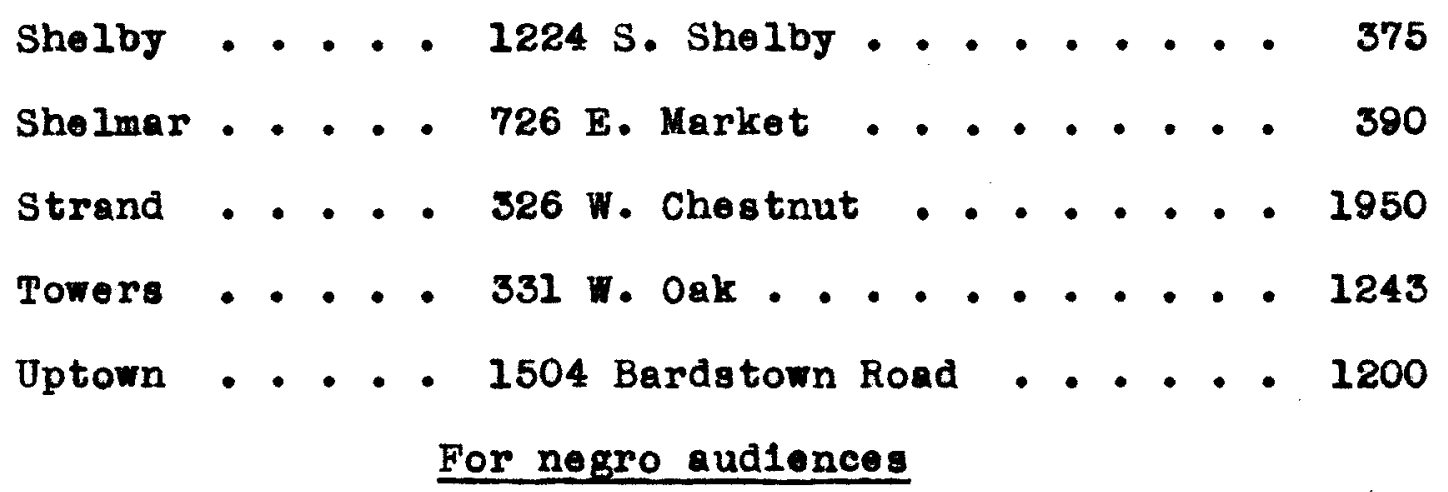

*D1xie... . . Preston and Caldwell . . . . 280 *Lincoln. . . Mirteenth Stroet near Walnut. - 677 Ljric . . . . 604 W. Walnut . . . . . . 800 Grand - . Walnut betireen S1xth and Seventh 655 *Palace . . . Talnut near Thirteonth..... 603 It can be seen from the above 11st that the geograph1cal distribution of Loulgville's movie theaters is good, although it is rather surprising that there is no theater on Bardstown Road beyond Eastern Parkway.

of these theaters the Strand, the Rialto, the Mary Anderson and Loew's are first-mun houses. The Brown is also a first-run house, but shows only pleturés which are held over from one of the other first-run houses. The Kentucky is a second-men house, and all the others are either second-or third-run houses. The strand, Rialto, Kentucky and Uptown are owned and operated by the Fourth Avenue Amusement Company. The Brown takes plctures. from any of the first-run houses except the Mary Anderson, which does its own holding over. Interviews with the managers of the local theaters make it plain that the managers have a spirit 
of cooperation rather than of competition. While practically all of our theaters have block-booking (and like it), the managers have some cholce in the solection of thelr f1lms. For oxample, both Loew's and the Rlalto rejected Our Town. The Strand accopted 1t. The managers try not to have two good pictures of the same type in town at the same time, but in this they are not always successful.

How does Loulsvillo avall itself of its opportunities to attend moving pictures? The first-run houses report that their combined average attendance, except in July and August, is approximately one hundred thousand people weok. In July and August it is considerably less. Unfortunately there are no statistics avallable from the nelghborhood houses. Their managers say they would not know how to make an estimate of their attendance. Their box-office recelpts tell very little because of the large number of children who attend and because all the nelghborhood theaters have one night a wook (usually Monday) when they admit two poople on one ticket. But we can get some 1 dea of their attendance from the following facts: The total soating capacity of the five theaters reporting an average of one hundred thousand weokly admissions is 10,021 . They have twenty-olght performances a wook, except the Mary Anderson, which bas thirty-four. The total seating capacity of the theaterg not reporting on their attendance 1s 19,763. Most of these theaters have only sixteon performances a weok, though a few have more. However, 
the number of performances probably does not have a very great effect on the number of admissions, as throughout the United States, seventy per cent of all people who onter the moving pictures theaters arrive betweon seven-thirty and elght-thirty P.M. ${ }^{1}$ In sumer our neighborhood houses are usually filled nearly or wholly to capacity. In winter their attondance is less. Wo can, therefore, estimate very indefinitely that the average attendance in the nelghborhood houses is somewhat above that of the first-run houses. But we can say with cortainty that Loulsvilliang attond moving pictures in sufficient numbers to make motion pictures an important factor in the life of the city.

In order to surmise what influence motion plctures are having upon the city, we must ascertain the type of pictures which the Louisville public is seoing. This quest1on can be answered only by the managers of our local the aters.

Mr. Hunt, manager of Loow's, states, "What the poople want now is a chance to laugh." He says that the comedy type of pleture is always popular in Louisville, but has been especially so sinee the present war began. By comedy, he 18 not referring to the "custard-p1e" type but to something more really human, as the Hardy Family plctures, Mr. Deods Goes to Town, or plctures with a touch of subtlety,

1. The Story of Moving P1ctures, Milestones of Progress, mimoographed material from the Motion Picture Producers and Distributors of America. 
as Ninotchka. He says also that musical comedios and light operas are very popular in Loulsville. Next to comedy, he says, action or adventure pictures go best, but always there must bo human appoal, and usually romance. At present there must be nothing to provoke serious thought. For example, Mortal Storm, an exceptlonally good plcture with popular stars and made from a popular novel, drew poor houses, undoubtedly because it provokes too much serious thought about the present world situation. At present the Loulsoille public is decidedis tired of blographical and historical plotures. Mr. Hunt finds that of course the stars appearing in a plcture have great deal to do with the size of the audience, but that one star usually means littlo--1t must be a toam as Nelson Eddy and Jeanette MacDonald or William Powell and Myrna Loy. Furthermore, he feols that not even the most popular of teams w111 draw a good audience unless they have good vohicle. He feels that plays made from popular novels (modern or old) draw well, provided they have good actors. In other words, todayls audiences in Loulsville want a good story, good acting, good dirocting and good sottings. In short, he says, our audiences have loarned to recognize a good film whon they see one and are not satisfled 1th mediocre plctures. The attitude of the Louisvilie public toward what Mr. Hunt calls the "hoary classics" is quite interesting. He says that any suggestion of the "high-brow" scares away the 
masses, ${ }^{1}$ but that the peoplo who do see the so-called "h1gh-brow" p1ctures, like them immensely. For instance, Romoo and Jullet drew a small audience here, but a questionnairo sent to working girls showed that the few who saw it liked it very much indord. Romeo and Jullet was "absolutely tops" in very largo cities, but a complote fallure in small towns. Captains Courageous, in spito of its lack of romance, was woll liked here, as elsewhere. Mr. Hunt attributes its succoss to good acting and directing, human appeal and action. Mr. Hunt foels that overy time the public soes plcture of very high standards the public taste is ralsed, which accounts for the goneral upward trend of plctures. His point of viow backs up Will Hays' statement quoted in Chapter one.

Mr. Hunt lists the following pictures as having brought in large audiences: The Hardy Family (any and all of them are absolutely tops with our audiences because of Mickey Rooney and the comedy, and because they are about people whom anyone can understand), Gone with the Wind, The Women, Another Thin Man, Young Tom Ed1son (10s8 popular, howover, than most M1ckey Rooney pictures), Mr. Smith Goos to Washington, Babes in Arms, Northwest Passage, Thunder Afloat and Grapes of Wrath. Mr. Hunt states that it is his definite opinion

1. All of our local theater managers speak froquently of the "masses" and the "elite." By the former, they moan the uncultured major portion of their audiences; by the latter, tho intellectual for. 
that the culture of the city is more refloctod in, than affected by, moving pletures. He points out, very logically, that the producor and exhlbitor must give the public what it wants or go broke. Nor is this condition poculiar to twontioth century America. He noted that the same state of affalrs existed with Ar1stophanes and Eurip1des.

At the present moment Dr. I. Q. 1s running a series of programs at Loow's. As his sories is not jot finishod, complete statistics are not avallable, but it is interesting to note that on his first night here, the Loulsville audience had a highor rating than the audience in any other city which Dr. I. Q. has visited. Loulgvilio's first night score was $3.2 \%$ above the next highest c1ty and $39 \%$ above average. Other citios which Dr. I. Q. has visited Include Boston, Philadelphia, Chicago, Salnt Louls, Dallas, Denver and Atlanta.

Mr. Musselman, manager of the Rialto, agrees substantially with the opinions expressed by Mr. Hunt. Mr. Musselman omphasizes the public's present desire for comedy, the fact that both stars and a good play are nocessary to the success of a picture, and that Louisville demands good p1ctures. For 1nstance Errol Flynn was a groat succoss in The Charge of the Llght Brigade, but a box-office fallure in the weak vehicle, Another Dawn. Mr. Musselman also calls attention to the brovity of tho average star's popularity. He says that the theater which today advertises Greta Garbo, 
Marlene Diotrich or Mao West is certain to have a poor audience. All of these stars were once public 1dols. Shirley Temple, too, has had a marked decline in popularity in the last year. Mr. Musselman seomg to foel even more strongly than Mr. Hunt that romance is essential to the popular success of a pleture. He quotes as evidence his experience with Deanna Durbin's pictures. One of her best pictures, in his ostimation, was A Hundred Men and a G1rl, a picture in which Stokowsk1 and the Philadelphia Symphony Orchostra played prominent parts. The picture had the best of music (though it was not too hoavy), and excollent comedy, acting and directing. But so far as Loulsille is concorned, it was a bad fallure. Mr. Musselman says that the audience was scared off in the first place because the masses wore afrald of Stokowsk1, and the real musiclans felt he would be in an incongruous setting. Thon the fow of the masses who came to the early shors missed the romance and the pleture got no bulld-up. My own opinion of the pleture colncides fully with that exprossed by Mr. Mussolman. It was oxcellent musically and dramatically. Mr. Musselman atates that the producers learned by the experience and that now there is always some romance in Deanna Durbin's plctures. The rosult is that she now draws huge audiences in Loulsville and almost evergwhere 01se. Mr. Musselman also says that plays made from popular novels have much appeal, and that blographical and historlcal 
pletures are dead in Loulsville. He gives as his most popular recent pictures: March of Time (the popularity of these plctures was immediate and is increasing constantly; the public likes drama with 1 ts news, and also onough of one subject to really mean something), Bringing Up Baby, Snow White, The Road to Singapore, My Favorite Wife, Irene, Primrose Path, and all Deanna Durbin pictures. The Rialto recentis made an interesting experiment in regard to the public's opinion of double features. The management asked all patrons of the theater for one woek to tell whether they preferred single or double features. Fifteon per cent more declared in favor of single features than double. So the theater adopted a policy of single features. Immedately 1ts attendance fell off greatly. It then reverted to double features, and the attendence wont up. Mr. Musselman said that with single features his balcony was empty; with double it 1s usually full. H1s interpretation is that young men can take their "dates" to a double feature in the balcong for sixty-six conts, and that when the show is over it is too late to have to go any place else and spend more money. He says that from the producers' angle there are two main reasons for double features. One is that in many c1ties, as Loulavillo, the public has become accustomed to good plctures and is not satisfled with mediocre ones, but that it is impossible to produce enough really good ones to supply the theaters with 
the large number necessary with single features. Another reason is to give some experience and publicity to rising players, which was formerly done through the legltimate stage. The Mary Anderson is the only theater in Louisville which regularly shows single features.

Mr. Buechel, manager of the Mary Anderson, rolterates that the public is now demanding comedy. He too feols that several stars and also good play are requisite to the boxoffice success of a plcture. He states, however, that when Bette Davis is in a plcture, nothing olse is noeded to attract good audience. He notes, though, that most of her pletures have had good stories. He says that to the average Louisville audience, the ending is the all-important part of the story. He seems to belleve even more strongly in the popularity of the action picture than does either Mr. Hunt or Mr. Musselman. He disagrees with most of the other managers in regard to the present popular appeal of the musical f1lm. He says that they were popular, but that now "musical comedy has died a horriblo death." He attributes its decease to the fact that there has been too much sameness in the stories of the musical comedies--they are all elther back-stage stories or storles of the sudden rise of a radio star. He is even more emphatic than the other managers that the blographical movie is doad. He cites as - vidence poor houses for Zola and the Magic Bullet. Mr. Buechel's comments on Loulsville's reaction to 
41

"hoavy classicg" is onlightening. Ho says that the critics, the Better Films Council and the intellectuals generally ask for higher typo plctures, so the producers and exhibitors provide them at onormous cost. Then they play to nearly empty houses. He gives as an examplo M1d-Summer N1ght's Droam. Its roviows wore excollont and several local groups, notably the schools, agroed to support 1t. The regults of their ald were moagre. Only thirty tickets were sold through the University of Loulsville and only glxteen through the Atherton High School. Yot, the fow people who saw the plcturo were enthusiastic. It is interesting to note that on the legitimate stage Loulgville has for many gears recelved Shakespeare well. Mr. Harry Martin, former manager of Macauley's and the Brown, and present manager of the Columbia Theater, says that Shakespeare on the legitimate stage is profitable in Loulaville unless done by a poor company. Southern and Marlowe brought packed houses, Robert Mantel and Fritz Lelber very good houses. According to Mr. Martin, Macauley's and the Brown always made it their policy to have one Shakespearean engagement overy season. The fact that Shakespeare in Loulsvillo is better attended on the logitimate stage than in the moving pictures probably means simply that the masses, who compose the bulk of the movie audiences but not of stage audiences, are not attracted by Shakespeare. It indicates nothing in regard to the 
culturally ollto.

Mr. Buechel gives as some of his most popular

recent p1ctures: Elizabeth and Essex (crowds due to Bette Davis and Errol Flyn), Dodge C1ty, Union Pac1f1c, and All Th1s and Heaven Too.

Mr. Fleld, assistant manager of the Strand, agrees In essentials with the opinions expressed by the other managers. He differs, however, from Mr. Buechel in that he says that musical pictures take very woll indeod in Louisville. He feels too, even more than other managers, the importance of the star. Apparently he does not even feel that more than one star is necessary. As he words 1t, "The star solls the plcture." He certainly foels that the blographical picture is not taking well here, and cites as an example a miserable house for Abe Lincoln in Illinols. This plcture, in a private showing for a group of civicminded citizens, olicitod most onthusiastic comments, as 1t did from the critics. Yot it did not attract the masses and consequently was a box-office fallure. Mr. Fleld polnts out, however, that there are usually specialized groups which are greatly interested in various blographical plctures. He says that local medical groups are now asking for the roturn of Pasteur, the Citadel and the Magic Bullet. He designates most of the classics as "sleopers," which means a plcture which attracts only a small audience at first, but pleases the audience to the extent that it advertises the 
pleture, and its attendance increaser gradually. He finds that the most striking example of a "sleoper" was the Count of Monte Cristo. The Blue Bird had a fairly good audience at the Strand in spite of Sh1rley Tomplo's recent docline in popularity. This was undoubtedly partly due to an exceptionaliy good B feature (a semi-musical comedy) and very attractive cartoon picture shown on the same program. Mr. Field gave no definite list of recent popular pictures. In fact he says there has beon an attendance slump in Loulavilie since about Fobruary. Other managers say the same thing but somewhat more mildly. The Brown is a first-run theater but shows only hold-overs. Mr. Greenwell, its assistant manager, states that the Brown is in a rather different position from other Loulavilie moving picture theaters not only because it has hold-overs but bocause it has a slightly different clientelo. For one thing, it gets many trangients from the Brown Hotel. He says that the local patrons of the Brown are rather more discriminating than those attending the other first-run houses as it is composed to a considerable extent of poople who do not go to see a plcture until they are reasonably sure it is good. Consequently, "sleoper" which is finenclally disappointing in the theater whore it is first shown can be a box-office success at the Brown. Mr. Greenwell agrees on most points with the other managers, but differs slightly in one instance. He alone of 
all the Loulsville managors says that the historical plcture takes well here. But he makes it clear that ho moans oplc or action pictures, not the ordinary historical blography. Even blographles go woll when they have action. Ho finds that all comedios havo groat popular appeal hero now, but that by far the most popular typo is the comedy of words. He too belleves that our audiences at present want nothing provoking sorlous thought on world conditions. Mortal Storm did not draw well at the Brown. Mr. Greenwell givos as recent "bost-sellers": The Hardy Family pictures (all of them), Kentucky, Ninotchka, The Road to Singapore, MI Favorite Wife, Irene, Drums Along the Mohamk, Northwest Passage, Jessie James, Union Pacif1c, and Lillian Russoll. Mr. SImon Swito, manager of the Kentucky, states that the plctures show in his theater, down-town secondmun house, are popular in the same degreo that they were in the first-run houses.

The same thing is true of the nelghborhood theaters, with a fow veriations. The audiences of the nelghborhood houses are composed largely of two extromes in ages--children and old poople. Both chllaren and old poople like child actors, therefore Jane Withers, who has poor audiences in the down-town theaters, plays to capacity houses in the nelghborhood houses. The Blue Blrd had packed houses at the Uptown. The thriller naturally goes well in the nelghborhood houses, but 1s usually shown as the B feature. At the Uptown, 
parents seem to exercise some supervision over the shows which their children attend. Mr. Boswell, the manager, says he recelves many telophone calls from parents inquiring if the picture he is showing is sultable for their chllaren to seo. But apparently, in most localities, children seo what they please. Of course the cartoon is an important part of the program in the nelghborhood houses. Mr. Boswell also senses a strain of sentimentality in his audiences. He says that many poople, espocially middle-aged or elderly women "love to have a good cry." In most instances, however, plctures are popular in the nelghborhood theaters in about the same degreo as they were in the first-run houses.

Some pictures which have had notable c1ty-wide success are: Kentucky, whlch had the all-time record run for Louigvillo. It showed continuously for six woeks and two days in the down-town theaters alone. The plcture with the second longest mun was Sunny S1de Up, in 1929. It showed continuously for six weeks. Other outstanding successes were Snow White, Gone W1th the W1nd, Naughty Marletta and One N1ght of Love.

Whon summerized, the gist of the statements of our motion picture theater managers seems to be as follows: Loulsville audiences are fairly discriminating in their appreciation of a film, but have not reached the highest level of appreciation, as is evinced by mass foar of the 
"high-brow." Nevertheless, it appears that our public is afrald of the word highbrow rather than of the actuality, for the fow who saw Romeo and Jullet, M1d-Summer N1ght's Dream and They Shall Have Muglc liked them. Unquestlonably, comedy at present holds first place in Loulsville, but it must be good comedy. Action plctures come next. But in olther type, this city wants human appoal and usually romance. The blographical picture is not popular here. The star, or stars, mean much to our public. A good story, especially one from a popular novel whether old or new, holps a plcture greatly. It soems that this city $11 \mathrm{kes}$ good music in a picture more than $1 t$ w111 admit. For example, our masses avolded Stokowski or He1fetz, but greatly enjoy really good music when lured to it by Deanna Durbin or Nolson Eddy.

This city's prodilection for comedy, action and stars, and its antlpathy to serious thought or blography are shared by the nation at largo. Its reaction to the "classics" and to musical films are Loulsville's own. 


\section{CHAPTER III}

\section{MOTION PICTURES AND THE FINE ARTS}

IN LOUISVILLE 
CHAPTER III

\section{MOTION PICTURES AND THE FINE ARTS}

IN LOUISVILLE

We have soen how Loulsvillo's taste is reflected through the type of motion pictures most popular in the c1ty. Let us now examine the effoct which these plctures may have upon the fine arts in Loulsville. We shall first consider motion pictures and literature.

In the course of its swiftly moving history the moving picture industry has doveloped many types of fllms, of which the most important today is the photoplay. Wo have already traced the high points of 1ts development in Chapter One. In nature the photoplay resembles both the novel and the stage play, jot differs from both. It resembles the stage play in that it is a diroct presentation of action and dialogue by actors whom we both seo and hear. It is like the novel in 1ts limitlossness and in 1ts mobility of time and setting. Both the novel and the photoplay can carry their public to any part of the globe and can utilize flash-backs and parallel action. The photoplay is, therefore, a combination of the play and the novel.

But it diffors from both in several vital respects. For one thing, it is much shorter. The length of the average photoplay is ninety minutes. Another great difference is that the motion picture is ephemeral in nature. The average 
audience is through with a moving picture when it has seon it once. A small portion of our audiences seo a picture twice, and occasionally there are revivals of old films, but the large majority of people seo a picture only oncel $0^{1}$ on the other hand, the play or novel can be road and reread, studied and conned over, wholly or in parts. Another difference is that the moring ploture has more complicated mechanics and technique than any other form of art. It is the result of innumerable mechanical Invent Ions--cameras, Kliog lights, sound recording, color photography and the coming stereoscope, or throe dimensional offect. Some of these have beon well mastered; one, color, partially so; and one, the stereoscope, is still in the conceptive stages. Each invention brings its problems of technique which must be mastered before artisticcreation can result. Then, when each problem has been mastered separately, there remains the task of blending them into one well-integrated whole--which is an art in 1tself.

Probably the most important point of difference between the photoplay and the stage play or novel is that the former is primarily a business enterprise. This fact is freoly admitted by both producers and oxhibitors. ${ }^{2}$ of course the novel and stage play have thoir business angles, but to nothing like the extent of the motion picture. The

1. WIII Hays Report, March 27, 1939.

2. Statement by Mr. Hunt, Manager of Loew's Theater. 
really great novelist or dramatist writes primarily to express himself. When he writes for more merconary reasons his works become pot-bollers, and are not great-are rarely even good. When it comes to production, a publisher can afford to publish a novel which will sell only to the intellectuals because the inftial cost is not too great. 1 A stago play always expocts to rockon 1ts audiences in thousands only. But a motion plcture, because of its enormous production costs, must attract its m111ions. Therefore, it is conditioned at every turn by the necessity of catering to popular taste.

There are cortaln esthotic principles which oither a tage play, a novel, or a photoplay must observe to be good literary art. They are unity, coherence and proportion, proper emotional appoal, and truth and reality. Let us soe how the photoplay compares in these respects with the stage play and novel.

In the observance of unity, coherence and proportion, the motion picture is subject to some peculiar temptations. For one thing, whon a producer is foaturing a popular, high salaried star, he is froquently tempted to give moro prominence to the character portrayed by that star than the perfoct whole warrents, as for example, Errol Flyn's role In the Prince and the Pauper. Th1s danger was one of the reasons given by some of the early producers for combating

1. Statement by Mr. M. K. Stewart. 
Carl Laemme's Idea of promoting stardom. Another serlous temptation is to omphasize unduly some particular scone, ospocially spectacular scenos as the arene oronts in tho Sign of the Cross. This temptation arises from two major causes--first, the expense involved in producing the scene, and second, that audiences long remember very vivid scenes. Also, all too often in color films, some scenes are overdone for the sake of color alone, notably desert scenes in the Garden of Allah. But in making a smoothly running plot, the photoplay has the advantage over either the stage play or novel. The motion picture is limited by nolther time nor sotting. It can utilize fade-outs, fade-ins, flashbacks and close-ups. Hence its advantages over the stage. In a novel, several minutes of reading are often required to describe an action which really occurs in only a fow seconds, but which the plcture shows in Its actusi time. From the beginning of the motion picture industry Amorican producers have shown considerable skill in handling plot. As mentioned in Chapter One, the real pioneer in this ine was the Blograph Company, under the dfrecting of David Wark Griffith. Today, American flims are noticeably better than most forelgn films, especiaily English films, in plot manipulation.

But this very facility in handing plot tends to produce woakness in another esthotic principlo--that is, in the proper handing of emotion. The fact that in photoplay 
action succeods action so rapidiy produces tenseness and a high degree of emotionaligm-moften too high a degreo. It is a distinct tendency of motion pletures to overdo omotional appeal in other ways too. This is usually more true of American pictures than of forelgn flims. It is probably done for two main reasons. One is because it is so easy to do. For instance, fire scones can bo mado vivid by sights and sounds natural to a fire, and by tho addition of photographic odditios, and oven musical accompaniments. The second motive which a director may have for holghtening emotional scenes is that audiences usually like them. We have already noted the present nation-wide desire for the wholesome emotion of humor. Then, considerable segments of American audiences (especially children) desire thrills; others delight in pathos and sentimentality; st1ll others, unfortunately, wallow in cruelty. Dr. Walter Barnes says of diroctors:

The1r reason for presenting the horrible is that the 1r audiences oat it up. No doubt wo 'reel back into the beast easily enough, no doubt wo retain vestiges of ancestral savagery, of delight in pain and anguish. But the artist, the woll-balanced, wollrounded artist, whilc he may oxplore those nether depths, does not exploit them, does not pander to our bestial passions, does not seok. to revivo primordial emotions whlch have no 'survival value' . . . The photoplay directors and the novelists who revel in sadism, mainly because there is a market for 1t, are perilously close, in attitude and purpose, to the Caesars who ptaged gladiatorial combats to make Roman holldays. 1

1. Barnes, Walter, Ph.D., Profegsor of the Teaching of English, New York University, The Photoplay as Literary Art, Newark, New Jersey, Educational and Recreational GuIdes, Incorporated, 1936, p. 33. 
Practically everyone over fifteon wants romance in movies--and gets 1t. But there is very littlo sexual Indecency in American moving pictures. Thero is nothing In them today to arouse lust, in fact the whole matter of sex is handled with much greater dellcacy and restraint In moving pictures than in elther the stage play or novel. This is due partly to censorship, and partly to the fact that moving pictures attract such mixed audiences as to make care in the handling of sex matters a necessity. In other words, our movies give us romance, but not sex. The two worgt sins of which the photoplay is guilty in 1to treatment of sex is its tendency to put romence in pictures whoro it has no place, as in Kidnapped, and to make it too trivial. Otherwise, to quote Dr. Barnes again, "Wo could regard the photoplay presentation of love as at its best boautiful and satisfying and at its poorest innocuous, unImportant, and, under the present circumstances, necessary."

The photoplay, however, has one great superiority over the stage play in the handing of emotional scenes. In a stage play which has many performances, an actor can scarcely be expected to play his emotional scenes oqually well at every performance. But a photoplay will make as many retakes as necessary until a really satisfactory result is attained and recorded for all times. From the comments of the managers of our local 1. Ib1a., p. 35. 
moving picture theaters, quoted in Chapter Two, it seems clear that Loulaville eudiences do their full share in demanding such emotional atrocities as excitement, sentimentality and romance-at-any-price. But they also seem to demand the wholesome emotion of humor, and in an intelligent form. It can also be said, to their great crodit, that while they like plenty of action, they show no great desire for cruelty. Not one theater manager in Louisville mentioned a horror pleture as among his most popular. In the presentation of reality and truth, in some phases the motion picture is vastly superior to the novel or stage play, but in most phases 1t is at present inferior. It is usually superior in settings. Obviously a moving plcture can present many scones which a stage play cannot, as storms at sea, battles, alr-plane flights, and so forth. In historical photoplays, not only the scenery but all the properties, settings and costumes are presented correctly, as the result of long research by woll-qualifled workers. of course the novel can describe scenes and settings truly and often beautifully, but psychologlcally no written description can produce the clarity and vividness of impression as does the actual visible presentation of the scene. In other types of films too, moving pictures today are making a great effort to present reality. An example 18 the popular Hardy Family plctures. Before this series was begun such questions were asked as "how many people 
compose the typical American family?" "In what sort of town would such famliy live? in what sort of house?" Research workers were sent to many towns in the Middle West to see the towns and houses. 1 The results have been that the Hardys are so typlcal of the American family that almost anyone, elther above or below the Hardy family's lovel, can understand it and soo his own family reflected in some phase of the Hardys.

often, however, human nature is distorted in a photoplay. One usual manner of doing so is found in the moving plcture's habit of altering the onding of a novel, which frequently results in changing characterization, as In Al1ce Adams. Another is the insertion of romance where It does not belong. A third is due to the star system, as sometimes a director will alter the character portrayed to sult the personality of the star. An extreme case of this sort is the character of Sara Crewe, as altered to suit Shirley Temple. A st1ll greater defect of the photoplay in the portrayal of character is that it cannot possibly admit the author's discussion of character. It cannot even include much dialogue which might reveal character because of the brevity of 1ts time. For the first three defects popular demand is often responsible. Certainly the managers of the Louisville theaters feel that

1. Letter from the Will Hays office of Motion P1cture Producers and Distributors of America. 
their audiences demand romance and happy ondings, and like to see their favorite stars.

Nevertheless, in many films characterization is very well done. For instance, both generalization and subtleties of character were excellently portrayed in Elizabeth and Essex, Captains Courageous and A Star Is Born. In Gone with the Wind certainly the characters wero not altered to sult the stars--to the contrary, long and arduous search was made for stars who would sult the characters. Some producers, too, are beginning to reallze that it is a mistake to make changes in plays or novels which they are making into pictures. David Selznick says:

I don't believo in reconstructing a story. I belleve, if there are fault $s$ in construction, it is better to keep them than to try to change them around, because no one can certainly plck out the chemicals which contribute to the making of a classic. And there is alwayg the danger that, by tampering, you may destroy the essential chemical. . . . The blggest job in adapting a well-beloved work is that of getting it down to the length of a foature $11 \mathrm{~lm}$. And I have discovered that the public will forgive jou any number of omisalons-particularly of subordinate material which is not connected with the main plot--but it won't forgive you deliberate alterations. For that reason $I$ find it best to make bridging scenes which span omissions as suggestive as possible. That is, by plcking up dialogue and oven phrases from other parts of the book, the audience is given the lilusion of sooing and hearing that with which thoy are already familiar.

In the presentation of general truths the photoplay is weak in comparison with the stage play or novel. It cannot enter into discussions because of 1ts brevity. 
Moreover, owing to 1 ts very inclusive audiences, it cannot deal with controversial matters, such as contemporary politics, denominational religion and sex problems. These questiona, if included in a photoplay at all, must bo treated with great restraint and ovasiveness. The motion plcture cannot attempt to ferret out the truth concerning them. ${ }^{1}$ In dealing with social problems the motion plcture is somowhat more successful, but it is still limited by its necessity for noutrality, and at present, it has the serious handicap of the public's aversion to thought-provoking films.

So wo soe that in many respocts the photoplay as literary art does not rank vory hlgh. Why then, do we take it serlously? For one reason, because it has potentialitios of greatnoss, and is rapidiy improving. If we doubt this we have only to compare a "revival picture" such as the Sho1k, considered of tho best in 1ts day, with a 1940 production, such as All This and Heaven Too. But the procoss of improvoment is circular in nature--producors and exhibitors provide better films when the public wants them, and public taste is 1mprovod gradualiy by seoing botter films. So progress 18 gradual, but 1t, has boen steady. Another resson for taking moving pictures seriously as literary art is bocause so many people soe thom. These poople, through the f1lms, become familiar with at least the general 1deas,

1. Statemants by Mr. Hunt, Mr. Buechel and Mr. Musselman. 
storles and characters of many plays and novels. Moreover, in spito of its ophemeral nature, the influence of a film upon the literary 1deas of our audiences carries over beyond the confines of the moving picture theater 1tself. In Loulsville, as elsowhere, films made from good plays or novels greatly stimulate reading.

The Loulsville Public Library reports that the moment advertisements appear of a motion picture based on a well-known play or novel, it has many calls for that book. It does not matter whether it is a modern book or an old ono-nall coples are borrowed immodiately and calls for It continue for several weoks after the picture has been shown in Lou1svillo. Moroover, the library usually has many calls for other books by the same author. It also has some calls for books on allied subjects. For example, after Marie Antoinotte was hero many poople wanted books on the French Revolution, and Lives of a Bengel Lancer and Gunga Din brought roquests for books about India. The library here cooperates with the motion picture theaters by displaying posters of worth-while plctures, and by giving out book-marks adverțising outstanding foatures. These book-marks are issued to libraries all over the country by the Motion Picture Producers and Distributors of America, from the Will Hays office.

\footnotetext{
1. Information furnished by Miss Winlfred Hutchings, Head of the Open-Shelf Room, Loulsville Froe Public Library, main branch.
} 
Mrs. Mary Sublett of the University of Loulsville library made abulation of reading connected with moving pictures. She gave out a questionnalre to one hundred and twonty-four students. The1r answers showed that 1083 than half of the students had read a single novel or play as a result of having seen the movie. She suggests as the main reason for this variation from the norm that the students have no time for recreational reading. However, the part of the questionnairo based upon photoplays dealing with historical events shows that quite a bit of reading has been done as a result of students having seen the movio. Many read b1ographlos of characters in the p1ctures. The oncyclopedias wore drawn upon for events connected with most of the films. Mrs. Sublett summarizes thus: "These results seom to indicate that moviog have stimulated reading of biographios and supplementary books more than the reading of the books themselves." I

1. Mrs. Sublett gives the following statistics, based on the answers to 124 questionnalres sent to students from freshmen to seniors.

Books read after the student had seon a plcture were: Anthony Adverge $\quad 17$ out of 51 Count of Monte Cristo 15 " " 50 Dav1d Copporfleld 15 " " 65 Grean L1ght 13 " " 39 Tale of Two Cit1es " 14 " " 84 Mrs. Sublett adds: "A goodly number were insplred to read Marle Antoinotte by $\mathrm{Zmo1g}$. . Sciontists such as Pasteur and Madame Curio wore read about o1 thor in biographies or in collections of blographies. The novels of Zola and the poems of Francols Vilion were read by several students.

"The encyclopedias were drawn upon for references to historical ovents centering around the times of In old Chicago, Parnoll, Suez, Lloyd's of London (ono person looked up the De Lesseps family in all the encyclopedias)." 
Our local book stores also report greatly increased sales of books made into moving pictures. This is true of books for chlldren as woll as for books for adults--and of different priced editions. Quite naturally, some of these books havo greater sales than others. Mr. W. K. Stewart, in discussing the type of book which sells well after a moving picture production, seems to echo the words of our local theater managers in regard to public taste. He says that books of romance or action usually sell best, regardloss of the age in which they were written. His sales records for all times wore broken by Wuthering Heights which sold in huge quantities in all sorts of editions, from twenty-f1ve cent paper backs to the best de luxe. The pleture had good audiences, but not extraordinary ones. other books whlch Mr. Stewart found had sales greatly stimum lated by moving pletures are The Good Earth (In the dollar edition-the twenty-five cent edition was not avallable when the picture was in Lou1sv1110), Grapes of Wrath, of Mice and Men, Captaing Courageous, Kidnapped, Gone with the wind, Phantom Crown (plcture Juarez), All This and Heaven Too, Snow White and Plnocchio. Of Mortel Storm, he sold only one copy and that was returned the next day. It had sold very woll when it was f1rst publishod. Mr. Stewart says that while some of these seles are to his regular customers; the majority of them are to people whom he never sees in his store at any other time. 
The experiences of the Hilderness Road Book Store are in the main those of the W. K. Stewart Company. Wuthering Heights, at the time the picture was here, broke all records. Other notably good sellers after the presentation of a plcture in Loulsvillo were: The Good Earth, All Th1s and Heaven Too, and Mortal Storm. The only apparent reason why the W1ldermess Road alone of all Loulsville book stores did well on Mortal Storm after the picture is its proximity to Loew's and the Brown theaters where the picture was shown, and to the Brown Hotel, whence it may have gotten some transient trade. But this seoms an inadequate explanation. Mr. Morton Joyes of the Milderness Road, says that be had a poor sale of the Magic Bullet, but that practically all other books made into moving plctures sell well. He adds that practically everyone wants the moving picture edition of a book when there is one. He believes that the reason is that 1llustrations made from a picture which the reader has seen give added vividness to his or her visuallzation.

Other book stores agreo egsentially with Mr. Stewart and $\mathrm{Mr}$. Joyes. It is interesting to note, too, that many stores which are not primarily book stores now handlo twentyf1ve cent editions of books made into moving pictures. Some of these stores are the Readmore Nows Stand, all the ten cent stores and dollar stores, and many drug stores. They all report thriving sales, and in the same proportion of 
popularity as given by Mr. Stowart. Therefore, we reach the definite conclusion that the motion picture is stimulating good reading in Loulsville.

While the photoplay is the most usual and probably the most important type of moving plcture, there are other types to be considered. One is the musical film. There are many musical comedies, though not so many as spoken comedies. Then there are a number of spoken comedies into which several popular musical numbers have been introduced, as The Road to Singapore. Both of these types, ospecially the latter, are popular in Loulsvilie but have 11ttle if anj cultural value. The next grade of musical film is the Deanna Durbin type-pictures which have ontertaining stories, stars with ploasing personalities, and four or five really good musical numbers. Other performers who have made this typo of plcture are Jeanette MacDonald, Nelson Eddy, Grace Moore, Gladys Swarthout, and Martini. In regard to both compositions and execution of music this typo of picture is a distinct cultural advance over the last mentioned sort of musical film. They have great popularity throughout the country, and even more In Loulsville than elsewhere. Next, there is the musical where there is some story, but where the real reason for the pleture is to feature some first class musician who 18 known solely as a musician, not as an actor. Examples are: They Shall Have Music, with Jascha Heifetz, Moonlight Sonata, with Paderemsk1, and Iffe and Loves of Beethoven, with Harold Bauer. 
The last two are foreign films. In fact, there are very fow films of this typo, bocause they have not met with popular favor in Loulsville or anywhere else in America. That moving pictures stimulate the composition of music is seen from numbers ospecially composed for many pictures, as Snow White and Gulliver's Travels. The use of original compositions is quite recent. It should bo interesting to observe its development. Incidental music is used in practically all feature films and in many shorts. It is interesting to note that this incidental music is usually by the best composers--selectlons from Beothoven, Tschalkowsky and Liszt are among those most frequently used. It is invariably well performed. But it is used only to heighten the emotional effect of a scene, never for its own sake.

In fact there has been virtualiy no attempt by moving plcture producers to treat music for 1 ts om sake. In the very early days of sound plctures a number of famous musiclans made shorts, but that type of plcture was soon discontinued, the basic reason being. that muglc alone does not utilize the essentially pletorial possibilities of the moving picture and can be quite satisfactorily presented by radio. There is still an unexplored field awaiting the motion plcture producers in the presentation of opera. The . motion picture should be able to produce something really great in this line. It is capable of exquisite scenic 
offects and it could produco better acting than can over be achloved on the operatic stage for this reason--the sound track can be made at one time and the action at another with only sotto voce singing, which allows the porformer to concentrate on acting. This is done now in most mus1cal plctures. There have been frequent rumors that one or another producer is about to undertake an opera, but so far, none has appeared, Eloubtless because such pictures would be subject to the same public attitude as the "hoavy class1cs."

Nevertheless, reports from Loulsvillo's music stores Indicate that moving pictures are having some desirable influence on the musical taste of the city. All music stores which handle phonograph records or printed mus1c report that sales in these articles are stimulated by moving pictures. Of course more of the popular type are sold than of the clasalcal--still the sale of the latter is gratifying. Mr. Paget of the Baldwin Plano Company says that after They Shall Have Music was shown in Louisville ho had many calls for Heifotz records of Tschaikowskj's Violin Concerto in D, and of Horra Staccato, which were used in the film. He says also that after the showing of any Deanna Durbin picture he has large sales of her songs, such as Gounod's Ah, que je voux vivre, and Schubort's Ave Maria. Ho finds that a musical film stimulates the sale of sheet music and phonograph records much more than do the "oporas" presented in the 
Iroquols Amphitheater. It is his opinion that public taste in music is boing gradually raisod by moving pictures. As he words 1t, "The public sees and likes movies with popular music, then it goes to music of the Strauss waltz class--and after that the next atep may be the highest."

It is interesting to note, too, the effect of moving pictures on music for children. All sheot music counters now have attractive childron's oditions of music from wollknown moving plctures, such as the Famous Music Corporation's book, Gulliver's Travels. This book has in 1 t all the songs from the pleture, arranged simply onough for very young mus1clans to sing or play on the plano. The arrangements, while very simple, have good harmony and make excellent studies for beginners. Each selection has an 1llustration from the moring picture. The book has sold very well in Loulsvilie. However, we must take into consideration that Louisvillo today is a music-loving c1ty. This can be seen from the fact that thore are more Steinway planos per capita in Loulsville than in any other city in the world. For the last ten years the Steinway agents here have maintained thoir position as third among the Steinway dealors of the world. This applios not to per capita sales, but to stralght number of salos. 1

In the realm of art, we find similarities to the

1. Information furnighed by Mr. Robert Shackleton, of the Shackloton Plano Company. 
films' use of music, in that there is a groat doal of inc1dental art, but very littlo art for art's sake. This is due to the egsential moving nature of the moving picture. Still, there is a large amount of art work in every photoplay made today. Every one has 1ta art director, who makes sketches for all sets. He even sketches the location of shadows, and the lighting offects of the film are arranged so as to prom duce the shadows desired by the art director. So every scene In a feature picture has some artistic value. Perhaps the - ffect produced is beauty, perhaps it is real1sm or horror-but it is art if we agree with Salamon Reinach that the object of art is "not to satisfy an immodiate neod, but to evoke a sentiment, a lively emotion--admiration, pleasure, curlosity, sometimes even terror."l

The only motion plcture which as yet has attempted to doal with a roal art subject is Rembrandt the Man, taken from Van Loon's book, The L1fe and Timos of Rembrandt van Rifn. It gave an excellent idea of Rembrandt as a man and as an artist. It portrayed well his artistic 1deals, and gave the spectator understanding of some of his works, espocially the somcallod N1ght Watch.

of course the color film has given a great impetus to art in motion pictures. In the early days of color, reds

1. ReInach, S., Member of the Institute of France, Apollo, an Illustrated Manual of the History of Art Throughout the Ages, translated from the French by Florence Simmonds, New York, Charles Scribner's Sons, pp. 1 and 2 . 
and greons predominated. Then, in an offort to correct this orror, fllms showed principally blues and yellows. But the three-color process made greater variety possible. Walt Disney, in Wyken, Blynken and Nod, made color into a plot. Mang of his and other cartoon pictures deal with color largoly for color's sake. It is interesting to know that one of Disney's orlginal pictures of the witch from snow White is now in the Metropolitan Museum of Art in New York. of course it is impossible to tell now whether this plcture will stand the test of time as a great work, but at loast it is significant as an innovation in the fleld of art. In Louispille, the Sign of the Pine Tree Art Store displayed with great pride at its opening a number of Walt Disney originals.

of course the cartoon pictures are drawn and painted-they are not color photography. The photoplay done in natural color photography still has tochnical difficultiog to overcome. For example, it is exceodingly difficult to make blues and reds register with oqual veracity in the samo scene, and close-ups of flesh tones are still unsatisfactory. Nevertheloss, much is boing accomplished in sheor artistry of color photography. Two films noteworthy in this respect are The Garden of Allah and Robin Hood. The former had 1 ts true raison detro in the color effect of desert scenes, especially at sunset. Weak in plot and sound, it was an artistic triumph. It was the art of strong contrast, and brilliant 
colors--gorgeous effects at their best. The color effects in Robin Hood are of an entirely different type. They are far more subdued than those in The Garden of Allah, and are a real study in subtlety. One of Louisville's well-known teachers of art, Mrs. Hildegarde Whitney O'Bannon, encouraged all her pupils to seo Robin Hood as a study in nuance in color.

In regard to applied arts, there is abundant evidence that moving pictures influence public taste in interior decorating and clothing. This toplc will be discussed more fully in Chapter Four.

The general effect of moving pictures upon the fine arts in Loulsvillo seoms to be as follows: In literature, people of the lower cultural levels are deriving real benefit from motion pictures. It is true that few of them as yet go to seo Shakespearean pictures, but they do seo and like pictures made from such books as K1dnapped, Captaing Courageous and Gone with the Wind, which are a distinct cultural advance for people of little or no culture. Sometimes, it is true, they get a distorted idea of the original, as in the Shirley Temple version of Woo W1llie Winkie, but usually they get at least the author's general 1dea, some familiarlty with characters of whom they would never have heard otherwise. Probably, too, many of these people are among those who buy. the cheaper editions of the books from which the pictures are made. People of the middle cultural levels are recolving 
considerable literary stimulus from motion pictures, both through attendance at the film, and through reading the orlginals and other books by the author, and books on allied subjects. People of the upper cultural lovels are apparentiy littio affected by motion pictures.

Very much the same conclusions can bo roached in regard to the influence of the motion picture upon the musical taste of Louisville. The lower cultural levels are lured to good music by the personality of a Doanna Durbin or a Nolson Eddy--and find they like 1t. For both lower and middle lovels, Mr. Paget's remarks cover the situation concisely. People of the highest cultural lovols in music, however, are little affected by motion plctures. In art, again the same general conclusions seem to be true--except that in this field, through attention to the artistic effect of every scene, moving pictures exert a continuous, though largely subconscious, influence towards artistic appreciation. As Margaret Farrand Thorp oxpresses 1t, "Movies are not only creating a hunger for art, they aro making art for millions of Americans a necessary and natural part of $11 \mathrm{fe} \cdot \mathrm{nl}$

1. Thorp, Margaret Farrand, op. cIt., p. 270. 
CHAPTER IV

\section{MOTION PICTURES AND EDUCATION}

IN LOUISVILLE 


\section{CHAPTER IV \\ MOTION PICTURES AND EDUCATION \\ IN LOUISVIILE}

It is true that those motion plctures which affect the fine arts are, in general sense, educational. But In this chapter we shall consider as oducational those plctures which convey information rather than those which give esthetic pleasure.

of these informational pictures there are several classes. The first is the pedagogical film, designed strictly for class-room use; next, such plctures as newsreols and travelogues; and last, photoplays which convey incidentally considerable general information, such as biographical and historical films. There are also certain technical films, such as pletures of intricate machinery used in some indugtries to teach workers about their machines. These, however, we shall not consider here, as they are vocational rather than cultural.

In examining the influence of the pedagogical film In Loulsville, we mugt turn to the schools. Throughout the country, schools have been slow in ut1lizing moving pictures, although where they have been thoroughly tested, it has been generally agreed that teaching by motion pictures has produced twonty-five per cent better results than any other kind 
of teaching. ${ }^{1}$ According to the census of 1930 there were approximately one hundred thousand school houses in the United States, and not more than ten thousand projectors, of which only about one thousand were sound projectors. Furthermore, slightly less than seven hundred were sixteen milimeter projectors. ${ }^{2}$ Th1s is important because sixteon milimeters is the standard size for pedagogical films. This means that throughout the country there is approximately one standard size sound projector for every one hundred and forth-three schools. Of twolve hundred teacher training institutions in 1937, slightly more than one hundred had courses in the use of films. 3 Most of these statistics, 1t $\$ 111$ be not1ced, were comp1led in 1930. More recent statistics are not avallable. The will Hays office of the Motion Picture Producers and Distributors of America belioves that in the last ten jears there has been some increase in the use of pedagogical films, but not a great deal, because of expenses involved.

According to Dr. Mark A. May, D1roctor, Inst1tuto of Human Relations, Yale University, there are four main reasons for the slowness of our schools in adopting the use

1. M1lestones of Progress-the Story of Moving P1ctures, Motion Picture Producers and Distributors of America-summary of results of Payne Fund research work, p. 10. 2. Statistics from W11I Hays offico.

3. The Motion P1cture in Education, prepared and published by the American Council of Education. 
71

of moving pictures. The first, he says, is a general tendency of educators toward conservat1sm; the next and most important, is lack of funds; the third is the lack of teachers who are adequately trained in the use of fllms; and last, deficiencies in distributing agencies. ${ }^{1}$ In 1930 there were about ten thousand educational fllms ava1lable. They were distributed by five hundred different agencies. The only note-worthy progress which the last decade has produced in the fleld of education by moving pictures has boen in the production of greater numbers of educational films and better teaching materials. Some of this work has been done by the research workers mentioned in Chapter One. Another achlevement is the excellent podagogical flims producod by the Educational Research Productions Industry, generally known as the Erp1 Instructional Sound Films. Their topics include social sciences, blom graphical sclonces, physical sciences, music, art, athletics and teacher training. Still other films, shorts, have boon made by the commercial producing companies, as the Vitaphone Company's See America First Series, and Metro-Goldwyn-Mayer's Miniatures. Furthermore, at the instigation of will Hays, the member companies of the Motion P1cture Producers and Distributors of Amerlca have opened their vaults of short

1. May, Dr. Mark A., Director, Institute of Human Relations, Yale University, "Educational Possibilities of the Motion Plctures," an address delivered before the National Educational Association Convention at Detrolt, July 8, 1937. Mimeographed copy from the Motion Picture Producors and Distributors of America. 
subjects to an advisory committeo of educators, who were invited to come and see what there is there of educational value. There are about fifteon hundred of these films, which cover every concelvablo subject. The reviowing and editing of them began on May 26, 1937, and is now nearly complote.

Good teaching material is now avallable for use in connection with both pedagogical and commercial films. Every pedagogical film is accompanied by a study guido. Excollont study guldes are available for comnercial films of literary or historic significance. The ploneer in this work was Dr. William Lewin. He is now Managing Editor of Educational and Recreational Guides, of which the General Editor is Dr. Max Herzberg, Principal of the Weoquahic High School, Newark, New Jersey. They are sponsored by an official Committeo on Photoplay Appreclation, appointed by the Division of Secondary Education of the National Education Asgociation. As many as five hundred thousand of them have beon sold for a single foature film. ${ }^{1}$ There are also other study guides publishod by varlous teaching organ1zations, and there are several good texts on motion picture appreciation for use in high schools.

The use of educational films in Loulsville compares favorably with that of the country as a whole, although there are many citios far in advance of Loulsville in that respect. 
There are one hundred and forty-four schools in the city today. 1 The Board of Education owns three sixteen mill1meter sound projectors. Four public schools own the1r own profectors, but only two of these four have sound tracks. Therefore, Loulsville has one sixteen millimeter sound projector for approximately every twonty-nine schools--for enough, but above the national avorage. ${ }^{2}$ Mr. Daugherty, who is in charge of motion picture work in the Board of Education, says that the projectors owned by the Board are almost constantly in use. The greatest handicap which the Loulsville schools have now in the use of motion pictures is that they have absolutely no library of fllms. Each school must provide its own films by whatever means it can. Mr. Daugherty is greatly interested in remedying this situation. He foels hopeful, for, he says, interest in oducational pletures here 1s enormous. He plans to begin in September to bulld up a film Ilbrary. The selection of films will be placed in the hands of a committee of qualifled teachers. He says that some of our schools, especially those which own projectors, sometimes show commercial films to ralse money. The Board of Education is not interested in such enterprises. It will back the use of pedagogical films only. Furthermore, some schools have shown commercial historical or biographical pictures to their pupils. In

\footnotetext{
1. Information from Bureau of Statist1cs, City Hall, Loulsville.

2. Information from Mr. D. E. Daugherty, Loulsville Board of Education.
} 
some cases the results have been unsatisfactory. Puplls would remember that "Norma Shearer" was born in Austria, rather than that Marie Antolnette was. Where such incidents occurred 1t was because there had been no time for bulld-ups. But where bulld-ups were made, the results were excellent. The University of Loulsville, in its 1940 summer session offered a course in visual education. This course Included study of available educational films, how to teach the films, care of equipment, and how to operate a projector. Among students enrolled in the course were thirteen school teachers. The course was conducted by Miss Lillian McNulty, who is well known throughout the country in connection with visual education. She has produced several educational films of outstanding merit. She says of oducational films, "The test of any picture is what it leads into. If a pleture dies with the seoing of 1t, 1t means nothing." Some of our schools, especially the funior high schools, have utilized the ducational possibilitios of commercial films by teaching motion picture appreciation. This has been done sometimes in regular classes, sometimes through motion picture appreciation clubs. Some of the most successful clubs were those of the Barrett Junior High School, the Eastern Junlor High School and Hallock Hall. A typical club is that of the Eastern Junior High School, under the direction of Miss Mary Barrett. The club, with from twentyf1ve to thirty members, meots weokly. As a group, Its 
members attend only "top-notch" plctures--about three a term. They leave the school at the beginning of the last period; therefore attendance at the movies is partiy on school time. Members attend other pictures in small groups, or as individuals. At the club meotings, the programs consist chiefly of discussion of study guides of current films. They are studied for both enjoyment and critlclsm. If as many as four or five members have seen a picture, they vote on whether or not it should be put on the club's list of recommonded films in the school paper. As these lists are complled by pupils, not teachers, they influence other children in the school in their cholce of pictures. Sometimes the local theaters will give a fow passes to puplls or teachers who wish to see a film which thej are considering recommending for group attendance. The first instance of this kind in Louisville was whon Loew's Theater gave four passes to David Copperfield, in 1935, to representatives of the Barrett Junior High School. The theater management was agreoably surprisod to find that the four returned with a group of one hundred pup1ls. Unfortunately, some of the moving picture appreciation clubs have recently been discontinued. The reason was not fallure of the clubs, but that the present pollcy of most of our public schools is to discontinue all clubs. However, much the same type of work is being done in many of the English or soclal science classes. 
It $w i 11$ be noted that the work just discussed applieg only to our public schools. The Catholic schools pay little or no attention to motion pictures, except, in some cases, to make avallable to pupils thelr lists of recommended films. None of Loulsvilie's non-denominational private schools utilize pedagoglcal fllms. All, however, occasionaliy show travel films and pictures of college ilfo provided by the colleges themselves. One private school, the Kentucky Home School for Girls, does considerable bulldup and follow-up work w1th commerclal pictures.

Most of Louisville's schools of secondary grade or above, encourage their pup1ls to attend French films brought here by the Louisville branch of the Alliance Francalse. Since the advent of sound plctures, the Alliance Francalse has brought two French pictures to Louisville every year. They are usually presented at the Towers, in two performances each. On these occasions, the theater, which has a seating capacity of twelve hundrod and forty-throe, is usually about three-fourths filled. The major portion of the audience consists of students. These films are carefully selected by the French government for exhibition in forelgn countries, but have little propaganda. They are selected from emong the best French productions of the year. However, because of the great inferiority of French to American films in technical effects and directing, only two of these pictures have been worth seoing purely as photoplays. But 
they help somewhat in famillarlaing the student with French speech. They are of great benefit to advanced students who have acquired a good understanding of the language and wish to retain 1t. Of course these pictures are not primarily educational in France, but they become mainly that when shown in Louisville.

Another type of motion picture which is definitely podagogical is the films used by the Louisville Board of Health in its program of public health education. These pictures are used sometimes in the city schools, but more frequently in dally vacation Bible schools and play grounds, where they are shown in a trailer. They deal with such subjects as The Story of Milk and Tuberculosis.

A great deal of information is conveyed to the public through commercial shorts which are not pedagogical. By far the most usual and popular of this type of film is the news-reel. In Loulsvilie as throughout the country, news-reels were popular in the very oarly days of motion pictures, then lost somewhat in popularity as the feature play developed, but regained and increased their popularity with the introduction of sound. As was mentioned in Chapter Two, the March of Time pictures are very popular in Loulaville--rather more so here than in most places. Probably these pictures have more educational value than the ordinary news-reel because they go more thoroughly into their subject. Also, their dramatic presentation gives them 
a vividness which makes them remembered longer. It has been argued that news-reels of any sort do little to increase public information because the audience already knows from nows-papers and radios all about what the newsrools contain. It is cortainly true that the majority of the public already knows about most of the contents of the nows-reol. But there is always some information in nows film which is still nows to many, and a groat deal which 1s nows to a fow. To 1llustrate: Loow's theater recently had a news-reel in which the Republican convention was shown. Naturally, there were elophants everywhere. Two girls in the audience were commenting on the picture. The girls were about fiftoen years old. Finally when some living elephants were shown, one girl said to the other, "I belleve elephants must have some connection with the Republican party." Then the plcture showed some soldiers embarking for Alaska. When the comentator said they were bound for the city of Anchorage, the girls exclalmed, "Have they got a town named Anchorage in Alagka too?", and "Anchorage! Well what do you know about that?" In case these comments seem oxtreme, it is well to remember that a largo part of our motion picture audiences is composed of the masses. But to even that portion of the audience to which the newg-reel conveys little new information it certainly adds vividness to the subject, and theroby makes it more Impressive. Moreover, through the news-reols, many 
Americans who lack opportunities to travel become familiar with the appearance of famous cities and bulldings all over the world, such as the Champs Elysees, the Hall of Mirrors at Versallies, the British Houses of Parliament, etc。 Today, there are few Americans indeed who are not famillar with the appearance of the New York shore-line and the National Capitol, thanks to the nows-reol.

In addition to the news-reel, there are innumerable other types of informational shorts show in Loulsvillo. Some of these are the Popular Science Series and Unusual occupations, both of which are very oducational and falrly popular in Loulavilie. The Crime Does Not Pay Series contains some information, but is of value chlefly for its possible social effects. However, the value of their social effects is extremely doubtful. The findings of the psychological research work done by Professors Dysinger and Ruckmick indicate that emotional response is to incident rather than to ideas--and that rotention of exclting scenes is far greater than of the final outcome of the picture. Therefore the public is much more apt to remember robberies, murders, etc., than the fact that the criminal pays in the end.

There are also many informational shorts not in series. Loew's recentiy exhibited an example of this typo of picture--a film callod Spots before Your Eyes. It was a Iively comedy in which was demonstrated the scientific 
methods of removing ink spots, grease spots and berry stains.

All of these various types of informational shorts convey a great deal of information. Much of it is specific rather than cultural. But it all helpg the cultural development of the city in that it broadens general knowledge and Interests.

There is also a wealth of general information obtainable from films designed primarily for entertainment, such a the photoplay or even the musical comedy. From attendance at the movies one can learn something of every phage of $11 \mathrm{fe}$, in every age and locallty. Obviously the historical and blographical pictures convey much information. Sometimes it is erroneous. The moving pictures' chief alm in this respect is the telescoping of events or otherwise altering the time sequence in order to make a well constructed plot of only ninety minutes' duration. But this tendency is rapldiy decreasing, and undoubtedly the movies heve an enviable reputation for accuracy in settings and costumes. Strictly modern plays too give considerable general information. They portray iffo in every conceivablo setting-hospitals, English schools, large citles, small towns and in the country. One can get some idea from the movies of practically every soclal strata and of every occupation. That these are often executed with verisimilitude can be seon from the approval of varlous professional 
groups, such as the medical groups which desire the return of The Life of Pasteur and The Citadel. Furthermore, the audience can gain specific skills from pictures-how to skin a figh, build an 1gloo, pack a circus--almost anything. An Immense store of knowledge concerning geom graphy and local customs can be acquired through the movies. Moreover, the masses can gain from the movies a good deal concerning good manners and proper living--such as how to enter drawing-room, what to do with a butler, and even something of how to dress.

In these lines, some segments of the gudience are much Influenced by the actorg themselves, and by commercial enterprises alliod with the moving pictures. Certainly actresses affect styles. After Romeo and Jullet, Norma Shearer's method of halr-dresging swept the country. Makers of beauty products spend huge sums in advertising that movie actresses use their products. In fact, commercial companies of all kinds connect their products with moving pictures. One hundred and forty-seven different concerns or Individuals are licensed to manufacture two thousand one hundred and elghty-three different novelty products based on Snow White. In 1930, $1 \mathrm{Mr}$. Bernard Waldman of the Modern Merchants Bureau, began to use tags in garments labelled "Clnema Fashions." The princlpal agency for them 1. Correspondence 1th Mr. Mililken, Motion Picture Producers and Distributors of America. 
Is Loulsvillo is Kaufman-Straus.

The taste of the Louisvilie public in interior decorating is plainly influenced by moving pictures. According to Mr. Frank Morris, of the furniture department of Kaufman Straus, black and white films have little offect upon public taste, but the influence of color films is considerable. He says customers frequently ask for furnituro and draperies like those in some current fllm. This was particularly true of Gone with the wind.

There are several agencles in Loulsville as elsewhere which are active in helping the public to get the most from its motion picture attendance. The ploneer here, as in most of the United States, was the Catholic Church, in 1ts moving plcture clean-up campaign. Today, the most outstanding of these agencies in the city is the Better Films Council of Louigville and Jefferson County. In 1933 the Federation of Women's Clubs Invited representatives of known organizations to a meeting which resulted, in 1934, in the formation of the Better Films Counc1l of Loulsvilie and Jefferson County. The original officers were: Mrs. Emmet Horine, president; Mrs. Lawrence Speckman, first vicepresident; Mrs. John L. Woodbury, second vice-president; Mrs. Ben Kohn, corresponding secretary; Miss Margaret Flynn, rocording secretary; Mrs. Raymond Clark, treasurer. Headquarters were at $532 \mathrm{~W}$. Main Street, and monthly meetings 
were held at the Brown Hotel. 1 The time of the formation of the Louisville Better Films Counc1l was the era of the lowest ebb of morality in motion pictures, as discussed In Chapter One.

The object of the Better Films Council, according to Mrs. Horine, is solely to guide the public, especially parents and guardians, in thoir cholce of films. She made it clear that the council is not a censorship organization, and is not concerned with morals as such. It hopes "through a process of enlightenment and education, to develop a desire for better movios." ${ }^{2}$ she put the blame for the poor moral tone of motion pictures of that time on the public rather than on producers or exhlbitors when she said, "Much has been said, and in rather loud terms, of the demand for better pictures in Louisvilie. Current reports indicate that some of the best clean pictures have met with poor success in Loulsville, while those deplcting crime, delinquency and other objectionable features have crowded our theaters." 3 The council began immediately to publish lists of recommended films in the Louisville papers and 19 still dolng so. These films are classified as for mature audiences, family, or young people. The council also established a library of books on films, and a speakers' bureau. Furthermore, it encourages the public to make inquiry by telephone

1. Courler-Journal, Aug• 26, 1934 .

2. Ibld., Nov. 14, 1935.

3. Ib1d., Sept. 28, 1934. 
concerning films. It also encourages the use of a little weokly paper, The Motion Picture and the Family, which contains comments on current films written by ducators and community leaders.

The Bettor Films Council of Loulsville and Jefferson County soon became well known among the Better Films Counc1ls of the country. At a two-day conference at the Brown Hotel, January 30 and 31,1935 , 1t had as a spoaker, Dr. Edgar Dale, Director of Educational Research at Ohio State University. He sald that the appreciation of moving pictures was boing taught admirably in Louisville. He asked that the results of a film study project conducted by M1sg Mary Hodge in the Barrett Junior High School be sent to him for publication in educational journals. ${ }^{1}$

By 1938, twenty-s1x organizations, civic, social, educational and religlous, had become associated with the counc11.2 In 1939, the counc1l, under the presidency of Mrs. Harry E. Stbley, undortook to contact the junior high school appreciation clubs. The present offlcers of the Better F1lms Counc1l of Loulsville and Jefferson County are: Mrs. Marle Dickson, president; Mrs. W. H. KInnard, first vice-president; Mrs. Roy Gabbert, second vice-president; Mrs. Howard Smith, corresponding secretary; M1ss Margaret Flynn, recording secretary; and Mrs. Harry Sibley, treasurer.

1. Ibld., Feb. 1, 1935.

2. Ibla., May 15, 1938. 
Another source of information concerning motion plctures in Louigvilie are our newspaper critics, of course, our papers, as those all over the country, publish some articlos which are intended solely to arouse interest in movies, as the articles by Shollah Graham in the Times and those by Louella Parsons in the CourlerJournal. But the comments of our own critics are plainly honest opinions of the films they are reviewing. Moreover, the reviows of two of our critics, Boyd Martin of the Courier-Journel and A. A. Dougherty of the Times, are of exceptionally high calibre. Both of these critics voted in the national annual poll to select the ten best pictures of the year. ${ }^{1}$ Mr. Martin's name is known to movie-goers throughout the country as a critic of unusual discernment. 2

It is questionable to what extent the Louisvilie public is influenced by the appreclation agencies. Undoubtedly the junior high school movie appreciation clubs influence puplis in the school in their cholce of films. Many parents read the Better Films Councli's classifications, but just how many cannot be determined. The attitude of children toward these classifications is doubtful. When the pupils of one of our private schools

1. FIIm Da1ly Year Book, 1937-1938, Publ1shed by Jack Allcoato.

2. Correspondence with Mr. Milliken, Motion Picture Producers and Distributors of America. 
were asked if they ever read the 11sts, most of them replied that they did, but said that they aroided the plctures listed for young people, as they were usually borlng. However, our moving picture theater managers, ospecially in the nelghborhood houses, feel that these lists have some effect on child attendance, probably due to parental authority. But our managers do not feel that nowspaper criticisms materially affect their box-office rocolpts. They say that criticism is essentlaliy for the intelloctuals, who read and onjoy them, but that the masses from whom the major part of our audiences comes, raroly read roviows. An lllustration is our Town, which had vory favorable roviews, but poor audiences. This is a nation-wide condition.

In summarizing the relation of motion pictures and education in Louisville, we can say that Louisville, as most c1t10s, has a largo, fort1lo, but chiefly unplowed, flold before it in the use of podagogical films. But, Iittle as Loulgvilio is dolng in this line, it is still somewhat in advance of the average of the country. From commercial films which convey general information, it is again our lowest cultural levels which are deriving very considerablo benef1t. The middle cultural lovels probably learn something, but the upper cultural levels are practically unaffected. The reverse is true in regard to newspaper criticisms. 


\section{CHAPTER V}

CONCLUSION 


\section{CHAPTER V}

CONCLUSION

The first general conclusion to be drawn from this study is that motion pictures are having a considerable influence upon the American public, culturally as well as in other ways. This is true for three main reasons: first, because a very large number of people attend moving pictures; second, because moving pictures deal with a great variety of subjects; and third, becauge, as show by reliablo psychological tests, motion pictures influence the thought and sometimes the behavior of those who see them. Evidently motion pictures are having as great an effect upon the people of Louisville as upon the people of the Unfted States as a wholo, becauge, first, there is no reason to think that our people are an exception to the usual psychological effects of motion pictures, second, because our exhibitors furnish the city with a great varlety of subjects, and third, because the averago motion picture attendance for Louisville is at least as large as that for the country as a whole.

In appraising the cultural tastes of the people of this city as reflected in the type of motion pictures which they attend, we must consider that the bulk of our audiences consists of the masses. Undoubtedly some of our most intellectual and cultured c1tizens attend the movies, but 
they are numericaliy a minor part of the audience. Therefore our moving picture audiences represent the city as a whole, not merely its upper strata. And in consideration of that fact, we find the cultural tastes of our city gratifyingly high. It is true that at prosent the loudest demand of our public is for comedy. But it wants chiefly comedy of words, or of real, human characters--not the slap-stick variety. The next most popular type of photoplay here is the action plcture. In this connection, let us note with pride that horror and cruelty draw lesser adiences in Loulsville than throughout the country as a whole. Most pletures made from good books have good audiences in Loulsville, which seoms to indicate that the public is interested in good I1terature. The popularity of the musical film gives evidence of a city-wide appreciation of good music. Of course the music in the musical comedy type film has no cultural value, but the music in the pictures of Deanna Durbin and others of similar kind has some value, and these pictures are very well attended In Loulsville. Louisville audiences show considerable interest in many strictly informational pictures. It will be remembered that Mr. Musselman of the Rialto lists the March of Time as among his most popular films. Popular Sclence and Unusual Occupations also go well here, which seems to indicate some intellectual curlosity on the part of our public. 
On the other hand, our motion picture attendance reveals some cultural deficiencies. Ono is our public's present aversion to thought-provoking pictures. However, this is perhaps a pardonable fault, in view of present world conditions. But other defects which cannot be so easily excused are the desire on the part of a considerable portion of our audiences for romance-at-any-price and happy endings. We may also regret the present lack of enthusiasm for historical or blographical photoplays. Furthermore, the highest typos of pictures, such as Romeo and Juliet, Mid-Summer Night's Dream and pictures foaturing Heifotz and Stokowsk1, have small audiences here. But let us remember that the few of our masses who saw these pictures liked them. Therefore the conclusion seems to be that the taste of our masses is more "high-brow" than they are willing to admit, and that, while it is not of the highest possible level, it is gratifyingly high.

What conclusions can we reach in regard to the effect motion pictures are having upon the culture of Louisville? In regard to literature, we can say that they do not have the highest possible effect because they cannot, or do not, probe general truths or controversial 1ssues. But they do stimulate good reading, and directly give many. people some familiarity with the general contents of works of literature of which, otherwise, they would remain ignorant. Sometimes these ideas are distorted, but the 
general trend of moving plctures is toward closer and closer adherence to the author's 1dea. In the realms of music and art moving pictures are having a slow but steady upward influence on our populace. In regard to all the fine arts, it seems that the moving pictures tend to raise the lowest cultural levels considerably, the middle levels slightly, and the highest levels not at all.

In the educational fleld, there seems to be much yet to be accomplished in the effective use of pedagogical films--but no more here than in the United States at large. Commercial informational films seem to be greatly raising our lowest cultural levels, slightly raising the middle levels and leaving the highest levels essentially unaffected. In comparing the city's culture as affected by, and reflected in, motion pictures we see that the process of improvement is c1rcular. 'Our exhib1tors give us better pictures when our audiences demand them, and gradually, by seoing better plctures, our audiences learn to want them. The whole history of moving pictures in Loulaville indicates continuous improvement in both the quality of plctures and the taste of the audience. 
BIBLIOGRAPHY

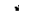

- 


\section{BIBLIOGRAPHY}

\section{Books}

Allcoate, Jack, editor, The F1lm Dally Yoar Book of Moving P1ctures, Ninotoenth Annual Edition, 1937.

Allcoate, Jack, editor, The F1lm Da1ly Year Book of Moving Pletures, Twent1oth Annual Edition, 1938.

Barnes, Walter, Ph.D., Professor of the Toaching of English, Now York University, The Photoplay as Literary Art, Newark, New Jersey, Educational and Recreational Guldes, Inc., 1936.

Beard, Charles A., and Mary R., Amerlca in Mid-Passage, Vol. II, Chapter XII, pp. 577-652, New York, The Macmillan Company, 1939.

Charters, W. W., D1roctor, Bureau of Educatlonal Kegearch, Ohio State University, Motion Plctures and Youth, A Summary, Now York, The Macml11an Company, 1933.

Drinkwater, John, Lifo and Adventures of Carl Laemmle, Now York, G. P. Putnam's Sons, The Knickerbocker Press, 1931.

Dysinger, Wendell S., Department of Paychology, State Un1versity of Iowa, and Ruckmlck, Christian, Professor of Psychology, State University of Iowa, The Emotional Responses of Children to the Moving Plcture S1tuation, New York, The Macmillan Company, 1933.

Griffith, Mrs. D. W., When the Movies Nere Young, New York, E. P. Dutton and Company, 1925.

Hampton, Benjamin B., A H1story of the Movies, New York, Covic1-Friece Publishers, 1931.

Hays, Will, See and Hear, A Brief H1story of the Moving Plcture and the Development of Sound, Motion P1cture Producers and D1stributors of Amer1ca, November, 1929.

Holaday, Perry W., Indlanapolis Public Schools, Getting Ideas from the Movies, New York, The Macmillan Company, 1933.

Low In, William, Photoplay Approciation in American H1gh Schools, National Council of Teachers of English, 1934. 
Perlman, W1ll1am J., compiler and editor, The Movies on Trial, the Viows and Oplnions of Outstanding Porsonal1tios Anent Screen Entertalnment Past and Present, New York, The Macmillan Company, 1936.

Ramsaye, Terry, A Mililon and One Nightg-A History of the Moving P1ctures, Vols. I, II, New York, SImon and Schuster, 1926.

Rotha, Paul, The Movie Parade.

Thorp, Margaret Farrand, America at the Movies, Now Haven, Yalo Univorsity Press, 1939.

Papers and Pamphlets

Hays, W111, President of the Motion P1cture Producers and Distributors of America, Annual Reports, 1937, 1938, 1939, (mimeographed copy).

Lou1sv1lle Courler-Journal, Fob. 10, 1916; 0ct. 6, 1921; July 2, 1933; Fob. 9, 1923; Apr. 3, 1927; Apr. 4, 1927; Aug. 26, 1928; Aug. 20, 1933; Feb. 1, 1935; Nov. 14, 1935; 1937-1940.

Lou1svillo Herald-Post, Oct. 2, 1923; Aug. 12, 1928; Sept. 2, 1928; Sept. 21, 1928; Fob. 1, 1930; Feb. 15, 1931;

Fob. 21, 1931 .

Lou1sv1110 Times, 1937-1940.

May, Mark A., Director, Institute of Human Relations, Yalo Univorsity, Educational Possibilitios of the Motion Plctures, an adress delivered before the National Educational Assoclation Convention at Dotrolt, July 8, 1937. Mimoographed copy from the Motion Picture Producers and Distributors of America.

Milestones of Progress, the Story of Moving Pictures, Motion Pleture Producers and Distributors of America.

Sterner, Allce and Bowden, Paul, A Course of Study in Motion P1cture Appreclation, Newark, New Jersey, Educational and Recreational GuIdes, Inc., 1936.

Study Guides to current p1ctures, Newark, New Jersey, Educational and Recreational Guldes. 
The Motion Plcture and the Family, published weekly by Motion Picture Producers and Distributors of America.

Variety, published wookly by Varlety, Inc., 1937-1940.

(Correspondence during a perlod of threo years with Mr. Carl E. Milliken, Secretary, Motion Plcture Producers and Distributors of America.

\section{Persons Interviewed}

Mr. Carl E. Milliken, Secrotary, Motion Plctures and Distributors of America, Now York.

Mr. Goorge Hunt, Manager of Loew's theater, Loulsville.

Mr. Johnson Musselman, Manager of the Rialto Theater, Loulsville.

Mr. Simon Sw1to, Manager of the Kentucky Theater, Louisvillo.

Mr. Buechel, Manager of the Mary Anderson Theater.

Mr. McCoy, Manager of the Strand Theater, former manager of the Uptown.

Mr. Field, Assistant Manager of the Strand.

Mr. Groenwell, Assistant manager of the Brown Theater.

Mr. Boswell, Manager of the Uptown; , Towers, Baxter and Ritz.

Mr. Dennis Long, Fourth Avenue Amusement Company.

Mr. Harry Martin, Manager of the Columbia Theater, former manager of the Brown and Macauley's theaters.

Mr. Pagot, Baldwin Plano Company.

Mr. Robert Shackloton, Shackleton Plano Company.

Clerks in phonograph record departments of wurlitzer's, Hole in the Wall, and Stewart Dry Goods Company.

Mr. W. K. Stewart, W. K. Stewart Book Company.

Mr. and Mrs. Morton Joyes, W1lderness Road Book Shop. 
Clerks in book departments of Stewart Dry Goods Company, Kaufman Straus, Keadmoro Nows Stand, all down-town Ten Cent and Dollar Stores, and three Walgreon Drug Stores.

Miss Winifred Hutchings, Head of the Open Shelf Room, Loulsville Free Public Library, main library.

Miss Evelyn Schnolder and Mrs. Mary Sublett, Library of the University of Loulsvilie.

Mass Lillian MaNulty.

Mrs. Hildegard Whitney O'Bannon, Teacher of Art.

Miss Helen Boswoll, Supervisor of Music, Loulsville Public Schools.

Mr. D. E. Daugherty, Louigville Board of Education.

Miss Mary Barrett, Director of Moving Picture Appreciation Club, Eastern Junior High School.

Mrs. Emmet Horine, former President of the Better Films Council of Louisville and Jefferson County.

Miss Margaret Flynn, Recording Secretary of the Better Films Counc1l. .

Father Pitt, Supervisor of Education, Catholic Church, Loulsville.

Mr. Frank Morris, interior decorator at Kaufman Straus Company. 